Article

\title{
Purification and Biochemical Characterization of Taxadiene Synthase from Bacillus koreensis and Stenotrophomonas maltophilia
}

\author{
Ashraf S. A. El-Sayed ${ }^{1, *}$, Maher Fathalla ${ }^{2,3}$, Ahmed A. Shindia ${ }^{1}$, Amgad M. Rady ${ }^{4}$, Ashraf F. El-Baz ${ }^{5}$, \\ Yara Morsy ${ }^{2}$, Basel Sitohy ${ }^{6,7}\left(\mathbb{D}\right.$ and Mahmoud Sitohy ${ }^{8}$ (D) \\ 1 Enzymology and Fungal Biotechnology Lab (EFBL), Botany and Microbiology Department, \\ Faculty of Science, Zagazig University, Zagazig 44519, Egypt; shindia-a@yahooo.com \\ 2 Chemistry Department, Faculty of Science, Zagazig University, Zagazig 44519, Egypt; \\ maherfathalla@gmail.com (M.F.); BiochemistDr92@gmail.com (Y.M.) \\ 3 Department of Chemistry, Faculty of Science, Islamic University of Madinah, Madinah 42351, Saudi Arabia \\ 4 Faculty of Biotechnology, October University for Modern Sciences and Arts, Cairo 12585, Egypt; \\ amgadmostafarady@gmail.com \\ 5 Genetic Engineering and Biotechnology Research Institute (GEBRI), University of Sadat City, \\ Sadat City 32897, Egypt; ashrafhawase@gmail.com \\ 6 Department of Clinical Microbiology, Infection and Immunology, Umeå University, SE-90185 Umeå, Sweden; \\ basel.sitohy@umu.se or bmzsitohi@hotmail.com \\ 7 Department of Radiation Sciences, Oncology, Umeå University, SE-90185 Umeå, Sweden \\ 8 Biochemistry Department, Faculty of Agriculture, Zagazig University, Zagazig 44519, Egypt; \\ mzsitohy@hotmail.com \\ check for \\ * Correspondence: ash.elsayed@gmail.com; Tel.: +20-1024686495
} updates

Citation: El-Sayed, A.S.A.; Fathalla, M.; Shindia, A.A.; Rady, A.M.; El-Baz, A.F.; Morsy, Y.; Sitohy, B.; Sitohy, M. Purification and Biochemical Characterization of Taxadiene Synthase from Bacillus koreensis and Stenotrophomonas maltophilia. Sci. Pharm. 2021, 89, 48. https:// doi.org/10.3390/scipharm89040048

Academic Editor: Helen D. Skaltsa

Received: 16 September 2021

Accepted: 21 October 2021

Published: 9 November 2021

Publisher's Note: MDPI stays neutra with regard to jurisdictional claims in published maps and institutional affiliations.

Copyright: (C) 2021 by the authors Licensee MDPI, Basel, Switzerland. This article is an open access article distributed under the terms and conditions of the Creative Commons Attribution (CC BY) license (https:// creativecommons.org/licenses/by/ $4.0 /)$.
Abstract: Taxadiene synthase (TDS) is the rate-limiting enzyme of Taxol biosynthesis that cyclizes the geranylgeranyl pyrophosphate into taxadiene. Attenuating Taxol productivity by fungi is the main challenge impeding its industrial application; it is possible that silencing the expression of TDS is the most noticeable genomic feature associated with Taxol-biosynthetic abolishing in fungi. As such, the characterization of TDS with unique biochemical properties and autonomous expression that is independent of transcriptional factors from the host is the main challenge. Thus, the objective of this study was to kinetically characterize TDS from endophytic bacteria isolated from different plants harboring Taxol-producing endophytic fungi. Among the recovered 23 isolates, Bacillus koreensis and Stenotrophomonas maltophilia achieved the highest TDS activity. Upon using the PlackettBurman design, the TDS productivity achieved by B. koreensis $(18.1 \mu \mathrm{mol} / \mathrm{mg} / \mathrm{min})$ and S. maltophilia $(14.6 \mu \mathrm{mol} / \mathrm{mg} / \mathrm{min})$ increased by $\sim 2.2$-fold over the control. The enzyme was purified by gelfiltration and ion-exchange chromatography with $\sim 15$ overall folds and with molecular subunit structure 65 and $80 \mathrm{kDa}$ from B. koreensis and S. maltophilia, respectively. The chemical identity of taxadiene was authenticated from the GC-MS analyses, which provided the same mass fragmentation pattern of authentic taxadiene. The $t d s$ gene was screened by PCR with nested primers of the conservative active site domains, and the amplicons were sequenced, displaying a higher similarity with $t d s$ from T. baccata and T. brevifolia. The highest TDS activity by both bacterial isolates was recorded at $37-40{ }^{\circ} \mathrm{C}$. The Apo-TDSs retained $~ 50 \%$ of its initial holoenzyme activities, ensuring their metalloproteinic identity. The activity of purified TDS was completely restored upon the addition of $\mathrm{Mg}^{2+}$, confirming the identity of $\mathrm{Mg}^{2+}$ as a cofactor. The TDS activity was dramatically reduced upon the addition of DTNB and MBTH, ensuring the implementation of cysteine-reactive thiols and ammonia groups on their active site domains. This is the first report exploring the autonomous robust expression TDS from B. koreensis and S. maltophilia with a higher affinity to cyclize GGPP into taxadiene, which could be a novel platform for taxadiene production as intermediary metabolites of Taxol biosynthesis.

Keywords: Taxol; taxadiene synthase; terpene cyclase; taxadiene; factorial design optimization 


\section{Introduction}

Taxol is one of the most traded, powerful antimitotic drugs and can cause cellular arrest during the G2/M phase of various tumor cells, including in leukemia, breast, ovarian, and lung cancer cells [1]. Taxadiene synthase (TDS) is a type I diterpene cyclase that catalyzes the first committed step of Taxol biosynthesis by cyclizing the geranylgeranyl pyrophosphate generating tricyclic hydrocarbon skeleton of Taxol "taxadiene" [2-4]. Taxadiene synthase, the biochemistry of Taxol biosynthesis, and different strategies for commercial Taxol production from endophytic fungi and plants have been extensively reviewed [5-10]. The emergence of endophytic fungi as a source of Taxol is a promising new avenue for commercial Taxol production due to their fast growth, cost effectiveness, independence from climatic changes, and feasibility of genetic manipulation [11-13]. Taxomyces andreanae was the first reported Taxol producer endophyte from Taxus spp. [2], followed by a plethora of endophytic fungi with Taxol producing potency from the Taxus species and other related plants $[5,6,9,10,14-18]$. Unfortunately, the exploitation of fungi as an industrial platform for Taxol production has been challenged by the loss of Taxol productivity due to fungal storage and subculturing $[11,12]$. Aspergillus flavipes and $A$. terreus, endophytes of Podocarpus gracilior, have been recognized as efficient Taxol producers for the initial cultures; however, their Taxol biosynthetic potency is strongly attenuated by subculturing and storage $[5,10,14-18]$. Several strategies have been proposed to restore the biosynthetic machineries of Taxol via fungi, such as the implementation of sterilized plant parts with the entire microbiome, which was able to dramatically restore the biosynthetic machinery of Taxol $[5,10,16]$, as well as cocultivation with the bacteria Bacillus subtilis, which had a significant effect on the Taxol biosynthetic machinery of A. flavipes [19]. Taxol productivity by A. flavipes was completely restored upon cocultivation with Bacillus subtilis due to the production of specific chromatin remodeling signals that triggered the expression of the fungal biosynthetic genetic cluster of Taxol $[9,16,19]$.

Downregulating the expression of the taxadiene synthase and the subsequent reduction on the cellular flux of taxadiene are the plausible metabolic traits that are associated with the attenuation of the Taxol biosynthetic machinery of fungi $[9,16]$. There are two types of diterpene cyclases: type I exhibits a single domain (a-domain) with the active sites of conserved motifs, including aspartate-rich motif $\operatorname{DDXX}(X)(\mathrm{D}, \mathrm{E})$ and the NSE triad $\mathrm{ND}(\mathrm{L}, \mathrm{I}, \mathrm{V})$ XS XXXE, which are mainly involved in binding the $\mathrm{Mg}^{2+}$ cofactor and form a trinuclear cluster for binding with the substrate diphosphate unit $[20,21]$. Type II shares a highly conserved DXDD motif for the protonation of the substrate [22]. Type I utilizes a trinuclear metal cluster to trigger the ionization of the isoprenoid diphosphate substrate to yield allylic cation and inorganic pyrophosphate [23]. The initial GGPP cyclization probabilities are determined via metal-dependent ionization and the departure of the diphosphate group between the first carbon atom and one of the following carbon atoms: $\mathrm{C} 6, \mathrm{C} 7, \mathrm{C} 10, \mathrm{C} 11, \mathrm{C} 14$, and C15, creating bond-forming reactions [23,24]. Terpenoids are categorized based on the type of carbon-carbon interaction during the initial GGPP cyclization reaction: C1-C11 (cyclooctatenol synthase), C3-C8 (entkaurene synthase), C1-C14 (taxadiene synthase), and putative labdane-related diterpene cyclase (LrdC) [23].

Given the high demand for Taxol in cancer chemotherapy, metabolic engineering approaches for the overproduction of taxadiene intermediates is one of the most recognized approaches. Several metabolically engineered microbes that can produce taxadiene have been reported, such as Escherichia coli [25] and Saccharomyces cerevisiae [26], which are dependent on the cloning of the TDS gene from T. baccata [27]. However, there are no reports describing the natural/wild presence of TDS in bacteria with autonomous expression that is independent of external signals from plant hosts; thus, searching for autonomously TDS producing bacteria as well as for methods for the the purification, biochemical, and kinetic characterization of this enzyme is the objective of this study. 


\section{Materials and Methods}

\subsection{Materials}

Geranylgeranyl pyrophosphate (Cat. \# G6025) and polyacrylamide solution were purchased from Sigma-Aldrich Co. (Saint Louis, MO, USA). Sephadex $\mathrm{G}_{200}$ and DEAESepharose were obtained from Pharmacia Co. Protein ladder (Blue Plus Maker, Cat. \# DM101, 14-100 kDa) was obtained from ThermoFisher Scientific, Massachusetts, USA. All other chemicals were of analytical grade.

\subsubsection{Isolation and Screening for TDS Producing Endophytic Bacteria from} Different Plants

Different plants, namely Mentha x piperita L., Coriandrum sativum L., Anethum graveolens L., and Moringa oleifera Lam., were collected from Zagazig, Alsharqia province, Egypt. Parts of the leaves and twigs of Podocarpus gracilior were collected from the Orman Botanical Garden, Cairo, Egypt, were washed thoroughly with sterile distilled water, and were sectioned into small parts. These parts were surface sterilized with $70 \%$ ethyl alcohol for $1 \mathrm{~min}$ and $2.5 \%$ sodium hypochlorite for $2 \mathrm{~min}$ and were rinsed with sterile distilled water to avoid any epiphytic microbial flora [28-30]. These sections were aseptically cultured on different solid media in plates containing potato dextrose agar (PDB, Difco), beef-yeast extract glucose $(0.15 \%$ beef extract, $0.3 \%$ yeast extract, $0.1 \%$ glucose, $0.6 \%$ peptone $)$, and nutrient agar $(0.2 \%$ yeast extract, $0.5 \%$ peptone and $0.5 \% \mathrm{NaCl})$ and were incubated at $30{ }^{\circ} \mathrm{C}$. The plates were incubated for 5 days, and the actively growing microbial colonies were selected and sub-cultured on the corresponding media. The selected bacterial colonies were eventually grown on Luria-Bertani (LB) medium (LB Broth Miller, Molecular Genetics, Granular) and were stored in $25 \%$ glycerol at $-20{ }^{\circ} \mathrm{C}$.

The metabolic producing potency of TDS by the recovered bacterial isolates was evaluated through growth on nutrient broth media [29]; An amount of $1 \mathrm{ml}$ of each bacterial spore suspension $\left(10^{3} \mathrm{CFU} / \mathrm{mL}\right)$ was inoculated into $50 \mathrm{~mL}$ media/250 mL Erlenmeyer conical flask and incubated at $30{ }^{\circ} \mathrm{C}$ for 4 days at $120 \mathrm{rpm}$. The bacterial cultures were pelleted by centrifugation at $8000 \mathrm{rpm}$ for $10 \mathrm{~min}$, the pellets $(1 \mathrm{~g})$ were washed, pulverized in liquid nitrogen, and dispensed in $5 \mathrm{~mL}$ HEPES buffer $(30 \mathrm{mM}, \mathrm{pH} 8.0)$ with $5 \mathrm{mM}$ sodium ascorbate, $5 \mathrm{mM}$ DTT, $1 \mathrm{mM}$ PMSF, $5 \mathrm{mM} \mathrm{Na} \mathrm{S}_{2} \mathrm{O}_{5}, 15 \mathrm{mM} \mathrm{MgCl}$, 10\% (v/v) glycerol, and $1 \%(w / v)$ polyvinylpolypyrrolidone $[3,16,17,31]$. The mixtures were shacked thoroughly and centrifuged at $8000 \mathrm{rpm}$ for $15 \mathrm{~min}$, and the supernatant was used as the source of the crude enzyme. Triplicates from each bacterial isolate were conducted, and the TDS activity was represented by the average. The activity of the crude TDS and the protein concentration were estimated described as below.

\subsubsection{Taxadiene Synthase Activity and Protein Concentration}

The TDS activity was determined according to the method proposed by Hezari et al. [3], with minor modifications $[6,9,15]$. Briefly, the reaction mixture contained $50 \mathrm{mM}$ geranylgeranyl pyrophosphate (GGPP), $5 \mathrm{mM} \mathrm{MgCl}_{2}$ in $50 \mathrm{mM}$ Tris- $\mathrm{HCl} \mathrm{pH} \mathrm{8.0,} \mathrm{and} 500 \mu \mathrm{L}$ enzyme extract of each bacterial isolate in a $2 \mathrm{~mL}$ total reaction volume. The reaction mixture was incubated at $37^{\circ} \mathrm{C}$ for $30 \mathrm{~min}$, which was stopped by $500 \mu \mathrm{L}$ EDTA $(0.5 \mathrm{M}$, $\mathrm{pH}$ 8.0). The GGPP concentration was determined by TLC with 60 F254 silica gel plates (Merck KGaA, Darm. Germany) with the developing solvent system, which comprised propanol, ammonia, and water (9:3:1) for the authentic GGPP (Cat. \# G6025). After running the solvent, the TLC plates were visualized using vapor iodine [32]. The intensities of the GGPP spots were determined using the Image J software package [33]. One unit of TDS activity was expressed by the amount of enzyme consuming $1 \mu$ mol of GGPP per min under the standard assay conditions.

The protein concentration used for the enzyme preparation was determined by Bradford's reagent using bovine serum albumin as the standard [34]. 


\subsubsection{Chemical Identity of Taxadiene}

The putative spots of the TDS byproducts were scraped-off of the silica, eluted by dichloromethane, and analyzed by gas chromatography-tandem mass spectrometry $[17,30,35]$. The chemical identity of the resolved putative taxadiene from the TDS activity of selected samples was resolved by GC-MS/MS (Agilent Technologies 7890A) interfaced with a mass-selective detector (MSD, Agilent 7000) equipped with a polar Agilent HP-5 ms (5\%phenylmethyl poly siloxane) capillary column $(30 \mathrm{~m} \times 0.25 \mathrm{~mm})$. The sample was injected $1 \mu \mathrm{L}$ with helium as a carrier gas, and the linear velocity was $1 \mathrm{~mL} / \mathrm{min}$. The MS operating parameters had an ionization potential of $70 \mathrm{eV}$, an interface temperature $250{ }^{\circ} \mathrm{C}$, and a mass acquisition range of 50-800. The chemical identity of the putative taxadiene was determined by relying on the comparison of their mass spectra and their fragmentation patterns using the NIST and WILEY libraries in addition to the fragmentation patterns of the mass spectral data of the authentic compound. The name, molecular weight, and structure of the components of the tested material were ascertained.

\subsubsection{Molecular Detection of TDS by PCR}

To confirm the spectroscopic and chromatographic activity of TDS, s molecular validation of the $t d s$ genes was conducted by means of PCR using bacterial DNA as a template [29]. Bacterial DNA were extracted with CTAB reagent $[30,36]$, which was used as the PCR template with the primer set $t d s 15^{\prime}$-GCAGCGCTGAAGATGAATGC- $3^{\prime}, 5^{\prime}$ CGATTCGATACCCCACGATCC- $3^{\prime}$ and $t d s 25^{\prime}$-ATGTCCAAACCCATGTCGAA- $3^{\prime}$, and 5-ACCCATGTCGAATTGAGAAGAT-3'. The PCR reaction mixture contained $10 \mu \mathrm{L}$ of $2 \times$ PCR master mixture (i-Taq ${ }^{\mathrm{Tm}}$, Cat. \#25027, iNTRON Biotech), $2 \mu \mathrm{L}$ of gDNA, and $1 \mu \mathrm{L}$ of the forward and reverse primers $(10 \mathrm{pmol} / \mu \mathrm{L})$; the reaction was completed by adding sterile distilled water until a volume of $20 \mu \mathrm{L}$ was reached. PCR amplification was performed using a Thermal Cycler 006 (A\&E Lab Co., Ltd., London, England), which was programmed for initial denaturation at $94^{\circ} \mathrm{C}$ for $2 \mathrm{~min}$, denaturation at $94{ }^{\circ} \mathrm{C}$ for $20 \mathrm{~s}$, annealing at $53-55^{\circ} \mathrm{C}$ for $30 \mathrm{~s}$, extension at $72{ }^{\circ} \mathrm{C}$ for $1 \mathrm{~min}$ for 35 cycles, and final extension for $2 \mathrm{~min}$ at $72{ }^{\circ} \mathrm{C}$. The PCR products were analyzed using $1.5 \%$ agarose gel, and the PCR amplicons were purified and sequenced using the same primer sets.

\subsubsection{Molecular Identification of the Potent TDS Producing Bacterial Isolates}

Potent TDS producing bacteria were identified based on their $16 \mathrm{~S}$ rDNA sequence $[29,33]$ using the universal primer set $5^{\prime}$-AGAGTTTGATYMTGGCTCAG-3' and 5'-CAKAAAGGA GGTGATCC- $3^{\prime}$. A loopful of actively growing bacterial colonies were suspended in $50 \mu \mathrm{L}$ lysis buffer $(10 \mathrm{mM}$ Tris- $\mathrm{HCl}, 50 \mathrm{mM} \mathrm{KCl}$ and $0.1 \%$ Tween $20(\mathrm{pH} \mathrm{8.3)}$, and they were incubated at $99{ }^{\circ} \mathrm{C}$ for $10 \mathrm{~min}$. A $1 \mu \mathrm{L}$ aliquot of the bacterial lysate was used as a template for the PCR amplification of the $16 \mathrm{~S}$ rDNA gene. The PCR reaction contained $10 \mu \mathrm{L}$ of $2 \times$ PCR master mixture (Cat. \#. 25027), $2 \mu \mathrm{L}$ of bacterial lysate, and $1 \mu \mathrm{L}$ of forward and reverse primers $(10 \mathrm{pmol} / \mu \mathrm{L})$, and the solution was completed with the addition of sterile distilled water up to a volume of to $20 \mu \mathrm{L}$. The PCR was programmed for initial denaturation at $94{ }^{\circ} \mathrm{C}$ for $2 \mathrm{~min}, 38$ cycles with denaturation at $94{ }^{\circ} \mathrm{C}$ for $30 \mathrm{~s}$, annealing at $55^{\circ} \mathrm{C}$ for $10 \mathrm{~s}$, extension at $72{ }^{\circ} \mathrm{C}$ for $30 \mathrm{~s}$, and a final extension at $72{ }^{\circ} \mathrm{C}$ for $2 \mathrm{~min}$. The amplicons were analyzed using $1.5 \%$ agarose gel in $1 \times$ TBE buffer with a DNA ladder and were sequenced using the Applied Biosystems Sequencer, HiSQV Bases, Version 6.0 with the same primer sets. The sequences were BLAST searched non-redundantly on the NCBI database and were aligned with the ClustalW muscle algorithm [37]; the phylogenetic tree was constructed using a neighbor-joining method with 1000 bootstrap replications [38].

2.1.6. Bioprocess Optimization of the Potent Bacterial Isolates for Maximizing Their TDS Yield by Two-Factorial Plackett-Burman Design and Faced Central Composite Design (FCCD)

The selected physicochemical properties, namely yeast extract, peptone, phenylalanine, tyrosine, tryptophan, glycine, valine, methionine, asparagine, cysteine, glutamic acid, 
beef extract, sucrose, glucose, xylose, $\mathrm{NaCl}$, ammonium nitrate, incubation time, and $\mathrm{pH}$ were optimized using a two factorial Plackett-Burman design to identify the significant variable affecting TDS production [35,39]. The nineteen variables were optimized using the Plackett-Burman design. Each variable was represented by high (+) and low (-) levels. The Placket-Burman design depends on the first order reaction:

$$
\mathrm{Y}=\beta_{\mathrm{o}}+\Sigma \beta_{1} \mathrm{X}_{1}
$$

where $Y$ is the predicted terpene cyclase production, $X_{i}$ is an independent variable, $\beta_{i}$ is the linear coefficient, and $\beta_{0}$ is the model intercept. All of the runs were conducted in triplicate, and the average of terpene cyclase production was used as a response.

The most significant positive independent variables affecting TDS production by the selected bacteria were optimized using FCCD to determine the individual and mutual interactions of the tested variables. In the FCCD experimental design, each variable was represented by three different levels, low $(-1)$, medium $(0)$, and high $(+1)$, and the center point was repeated six times, resulting in a total 20 runs.

\subsubsection{Purification and Molecular Subunit Structure of TDS from the Most Potent Bacteria}

The potent TDS producing bacteria were grown on the optimized enzyme production media from the surface response methodology using different factorial designs. After incubation, the bacterial pellets $(\sim 50 \mathrm{~g})$ were collected, washed with sterile potassium phosphate buffer (50 mM, pH 7.0), pulverized in liquid nitrogen, and dispensed in $50 \mathrm{~mL}$ of HEPES buffer comprising $1 \mathrm{mM}$ ethylenediaminetetra acetic acid (EDTA), $1 \mathrm{mM}$ phenylmethansulphonylfloride (PMSF), $1 \mathrm{mM} \beta$-mercaptoethanol, and $1 \mathrm{mM} \mathrm{CaCl} 2$ [8,40-43]. After homogenization, the mixture was vigorously agitated for $15 \mathrm{~min}$ and was then centrifuged at $8000 \mathrm{rpm}$ for $10 \mathrm{~min}$ to remove the cell debris. The supernatant was used as source of crude enzymes. The activity and protein content of crude enzyme were measured as above. The crude proteins were precipitated by two volumes of child acetone for $15 \mathrm{~min}$ at $-20{ }^{\circ} \mathrm{C}$, the precipitated proteins were collected by centrifugation at $10,000 \times g$ for $5 \mathrm{~min}$, and the protein pellets were dissolved in $50 \mathrm{~mL}$ HEPES buffer ( $\mathrm{pH} 7.4,50 \mathrm{mM})$ [8]. The precipitated proteins were fractionally concentrated with $20 \mathrm{kDa}$ cut-off dialyzer (Cat. \# 546-00051) against polyethylene glycol 6000 until the minimum volume was reached $(5 \mathrm{~mL})$. The enzyme was purified by means of the gel-filtration and ion-exchange chromatographic approaches [18-43]. The crude protein (2 $\mathrm{mg})$ was loaded into the column of Sephadex $-\mathrm{G}_{200}(2 \times 40 \mathrm{~cm})$ and was pre-equilibrated with $50 \mathrm{mM}$ potassium phosphate buffer ( $\mathrm{pH} 7.5)$ at flow rate $0.5 \mathrm{~mL} / \mathrm{min}$. The enzyme fractions $(1 \mathrm{~mL})$ were eluted with the same buffer, and their activity and concentrations were determined by the standard assay. The most active, molecularly homogenous fractions were collected and were concentrated by means of dialysis against polyethylene glycol 6000. The partially purified enzymes from the first step were further purified by ion-exchange chromatography using a DEAESepharose column $(2 \times 30 \mathrm{~cm})$ that had been preequilibrated with potassium phosphate buffer $(0.1 \mathrm{mM}, \mathrm{pH} 7.5)$. The sample $(1 \mathrm{mg})$ was loaded on to the top of the column, and after gel-permeation, the column was equilibrated with the same buffer at a flow rate $0.5 \mathrm{~mL} / \mathrm{min}$. The enzyme was eluted by gradient $\mathrm{NaCl}$ concentrations (100-300 mM) with the same buffer. The activity and protein content of the obtained fractions were determined by the above assay. The most active and homogenous TDS fractions were collected and were concentrated with $10 \mathrm{~K}$ ultra-centrifugal membrane and were stored at $4{ }^{\circ} \mathrm{C}$ for further analysis.

The molecular homogeneity and subunit structure of purified TDS were checked using SDS-PAGE [44] with slight modifications $[43,45,46]$. The molecular mass of the purified TDS was determined and was normalized to an authentic protein marker (Puregene, Cat. \# PG-PMT2962 315-10 kDa). The entire molecular mass of the purified TDS was determined by native-PAGE [44]. 


\subsubsection{Biochemical Properties of the Purified TDS from the Potent Bacterial Isolate}

The most active and molecular homogenous fractions were gathered for subsequent biochemical characterization [8,40-42,47-49]. The optimum reaction temperature for the TDS activity was evaluated by incubating the enzymatic reaction at $4,20,30,37$, and $45^{\circ} \mathrm{C}$, measuring the enzyme activity using the standard assay. The thermal stability was assessed by pre-incubating the enzymes without substrate at $4,20,37,45$ and $50{ }^{\circ} \mathrm{C}$, at $15,30,60$ and 180 and $240 \mathrm{~min}$, and then measuring their residual activities with the standard assay. The thermal kinetic parameters half-life time $\left(T_{1 / 2}\right)$, half-life temperature $\left(T_{m}\right)$, and thermal inactivation rate $(\mathrm{Kr} r)$ were determined [48].

The effect of the reaction $\mathrm{pH}(3.0-10.0)$ on the activity of the purified TDS were investigated using $50 \mathrm{mM}$ of citrate phosphate buffer ( $\mathrm{pH} 3.0-5.0)$ and Tris- $\mathrm{HCl}(6.0-10.0)$. The $\mathrm{pH}$ stability was evaluated by preincubating the enzyme at different $\mathrm{pHs}$ for $2 \mathrm{~h}$ at $4{ }^{\circ} \mathrm{C}$ and then measuring their residual activities by standard assay as described above. The effect of different inhibitors on the activity of the TDS activity was assessed. The purified enzyme preparations were desalted by dialysis (Cat. \# 546-00051, Wako Chem., Richmond, VA, USA) against $50 \mathrm{mM}$ Tris- $\mathrm{HCl}$ buffer (pH 8.0) of $1 \mathrm{mM}$ EDTA. Different cations, namely $\mathrm{Ba}^{2+}, \mathrm{Fe}^{3+}, \mathrm{Ca}^{2+}, \mathrm{Hg}^{2+}, \mathrm{Fe}^{3+}, \mathrm{Al}^{3+}, \mathrm{Zn}^{2+}, \mathrm{Na}^{+}$, and $\mathrm{Cu}^{2+}$ were added to the enzymes at a final concentration of $1 \mathrm{mM}$, incubated for $2 \mathrm{~h}$ at $4{ }^{\circ} \mathrm{C}$, and the substrate was then added, with the enzyme activity being measured by the standard assay. The influence of suicide amino acid reactive analogues, namely hydroxylamine, iodoacetate, guanidine thiocyanate, DTNB, and MBTH (1 mM final conc.), on the activity of the purified TDS was assessed. The mixtures were incubated for $2 \mathrm{~h}$ at $4{ }^{\circ} \mathrm{C}$, and then the residual activities of the enzymes were measured by the same standard assay as the one described before.

Statistical analysis: All of the experiments were conducted in biological triplicates, and the results were expressed by mean \pm STDEV. The significance and F-test were calculated using one-way ANOVA with Fisher's least significant difference post hoc test.

\section{Results}

\subsection{Screening for the Potent Taxadiene Synthase Producing Bacterial Isolates}

Twenty-three endophytic bacterial isolates were recovered from the surface of sterilized leaves of Mentha x piperita L., Coriandrum sativum L., Anethum graveolens L., Moringa oleifera Lam., and P. gracilior on the media PDA, beef-yeast extracts glucose, and nutrient agar (Table S1). These bacterial isolates were purified and stored on nutrient agar media. The TDS producing potency of the recovered bacterial isolates were assessed by being grown on PDB for 4 days at $30^{\circ} \mathrm{C}$, and the cultures were pelleted and pulverized in liquid nitrogen, and the intracellular proteins were extracted, and the enzyme activity and concentrations were determined by the standard assay. Among the recovered bacterial isolates, seven bacterial isolates, \# 10, 37, 38, 39, 40, 41, and 42, displayed the highest potency for TDS production (Figure 1). The highest TDS activity was produced by bacterial isolate \# $41(8.8 \mu \mathrm{mol} / \mathrm{mg} / \mathrm{min})$, followed by isolate \# $42(4.7 \mu \mathrm{mol} / \mathrm{mg} / \mathrm{min})$, while TDS production ranged between $1.9-2.6 \mu \mathrm{mol} / \mathrm{mg} / \mathrm{min}$ for bacterial isolates \# 10, 37, 38,39 , and 40. Interestingly, the highest TDS-producing bacterial isolates $(\# 41,42)$ were isolated as endophytes of $P$. gracilior, which is the host of the Taxol-producing endophytic fungal isolate $A$. terreus $[9,18]$. The TDS activity was clearly revealed from the residual concentration of GGPP on the TLC chromatogram, as shown on Figure 1 (upper panel). The biosynthetic potency of TDS was confirmed from the nested-PCR detection of the $t d s$ genes that were designed based on the conserved active sites sequences of the TDS from different fungal and plant sources. The metabolic producing potency of TDS by isolates 41 and 42 was confirmed from the positive PCR amplicons from the specific active site-designed $t d s$ primers (Figure 1C,D) compared to the negative TDS-producing bacterial isolates. The amplicons of $t d s 1$ were about $500 \mathrm{bp}$ for bacterial isolates \# 41 and 42 , while the $t d s 2$ amplicons were approximately $300 \mathrm{bp}$ for both bacterial isolates, and there was an absence of PCR amplicons for the negative enzyme-producing isolates. 
A
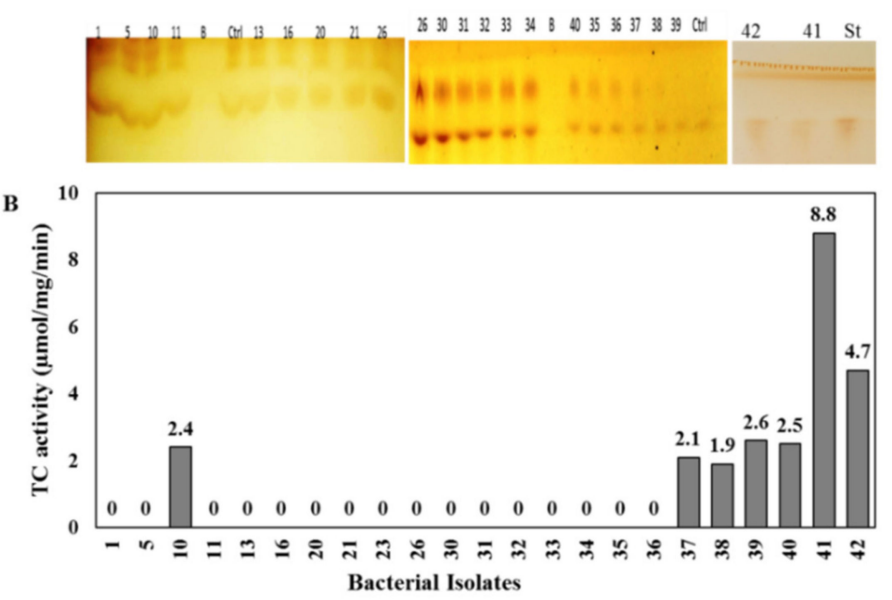
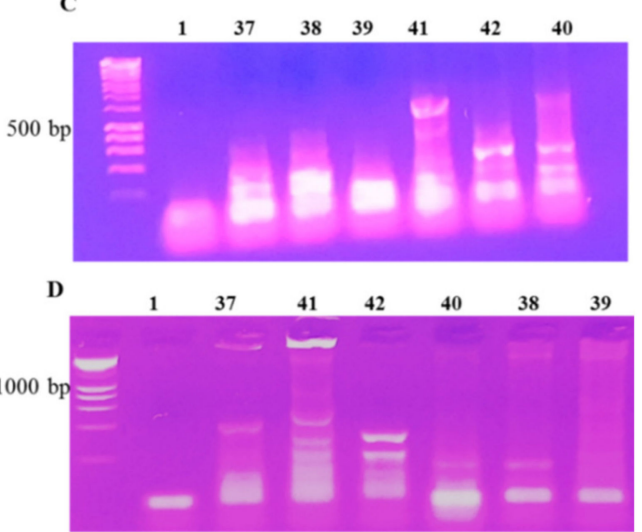

Figure 1. Screening for TDS production from different bacteria isolates. After incubation, the bacterial cultures were pelleted, the intracellular proteins were isolated, and the activity of crude TDS was determined. The TLC chromatogram of the residual GGPP (A) and the putative TDS activity (B) is shown. PCR amplification of $t d s$ from the selected bacterial producers using the active-site conservative primers TDS1 (C) and TDS2 (D) is shown.

The chemical identity of the released taxadiene as the byproduct of TDS activity was verified by GC-MS analysis. The enzymatic reaction of the putative crude TDS and GGPP as a substrate in HEPES buffer was incubated for $15 \mathrm{~min}$ at $30^{\circ} \mathrm{C}$, then the reaction mixture was spotted on TLC, and the developed plates were visualized by vapor iodine. The developed putative taxadiene spots were scarped-off and were analyzed by GC-MS. From the GC-MS profile (Figure 2), the fragmentation pattern of the parent and daughter molecules of the putative taxadiene samples was coincident to the authentic one. The molecular mass of the parent taxadiene molecule was $271.2 \mathrm{~m} / \mathrm{z}$ compared to the authentic taxadiene molecule, which was $272.1 \mathrm{~m} / \mathrm{z}[3,27]$. The fragmentation pattern of the parent taxadiene molecule as byproduct of putative TDS from bacterial isolate \# 41 generated common daughter ions of 57.1, 81,95,107, 122, 147.1, and 197.1, which is consistent with the fragmentation pattern of authentic taxadiene [27].

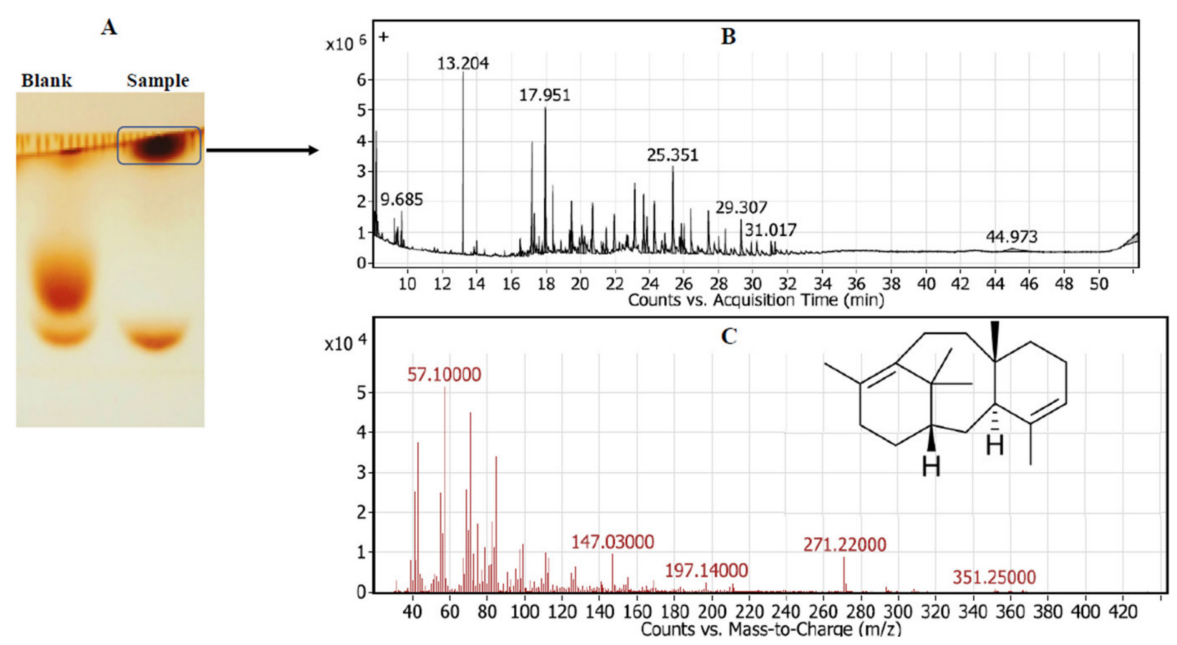

Figure 2. GC-MS analysis of the released taxadiene as a byproduct of putative crude TDS from Bacillus koreensis. After incubation of the enzymatic reaction, the enzymatic byproducts were spotted on TLC, and putative taxadiene spots were scraped-off of the silica gel particles and were analyzed by GC-MS analysis. (A) TLC chromatogram of enzymatic byproduct. (B) Spectrum of counts vs. acquisition time. (C) Mass spectrum of putative taxa-4,11-diene with the inset chemical formula. 


\subsection{Molecular Identification of the Potent TDS Producing Bacterial Isolates (\# 41 and 42)}

The potent TDS-producing bacterial isolates \# 41 and 42 were molecularly identified based on the sequence of their 16 S RNA region. Using the gDNA of these bacteria as a template for PCR, the size of the resolved amplicons ranged from 550-600 bp (Figure 3). These $16 \mathrm{~S}$ amplicons were purified and sequenced, and any that were non-redundant were BLAST searched in the NCBI database. Bacterial isolates \# 41 and 42 were identified as Bacillus koreensis and Stenotrophomonas maltophilia, and their 16S RNA sequences were deposited in the NCBI database with accession \# MN592666.1 and MN592660.1, respectively. From the alignment, applying the Neighbor-Join and BioNJ algorithm with the maximum composite likelihood approach, the phylogenetic relatedness of these sequences was constructed. Bacillus koreensis EFBL MN592666.1 displayed a 99\% similarity with the database-deposited isolates of B. koreensis MT102961, NR116851, MF151752, FJ389509.1, MH801097.1, MT214157.1, JQ026323.1, JN578481.1, GQ302985.1, and KC894754.1, with an E-value zero and a query coverage of 98\%. Stenotrophomonas maltophilia EFBL MN592660.1 had a 98\% similarity with the database-deposited S. maltophilia KP82608.2, KP165415.1, EU931549.1, JF711013.1, KC136828.1, FN645734.1, FR823396.1, MN192109.1, AJ131907.1, KT580665.1, KX817899.1, KF668478.1, KT580654.1, and KF463870.1, with an E-value zero and a query coverage of $96 \%$.

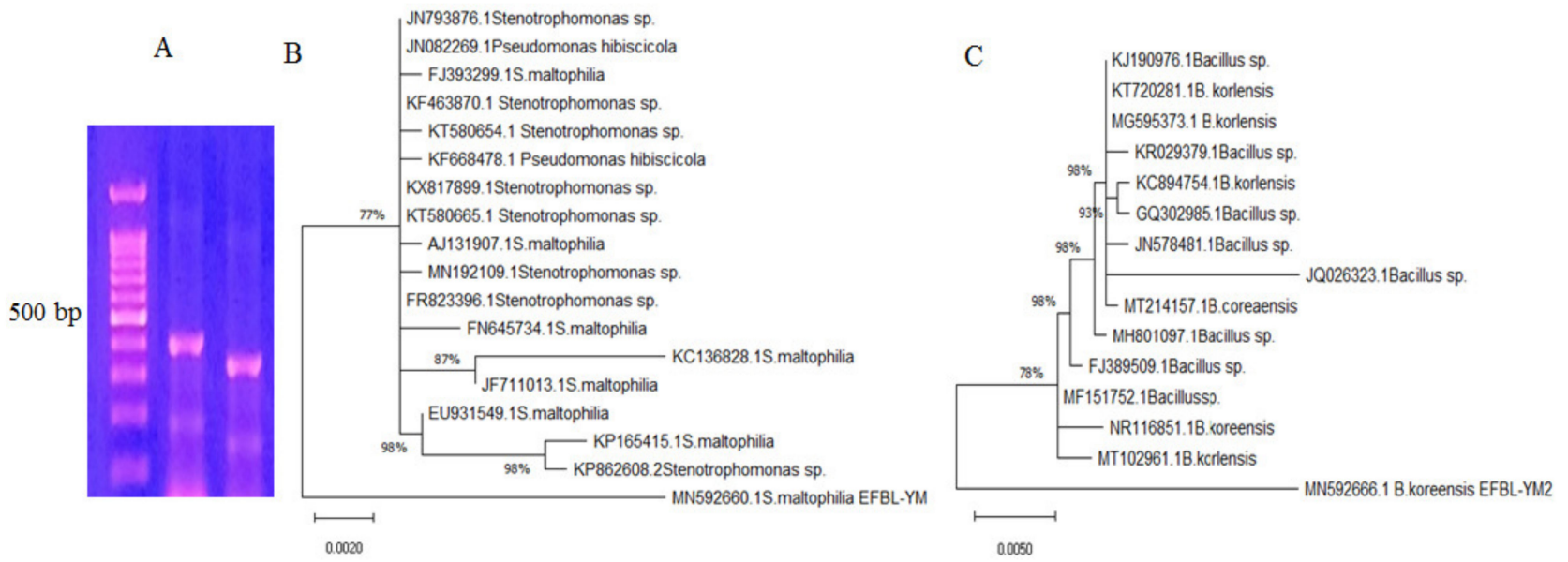

Figure 3. Molecular identification of potent TDS-producing bacterial isolates. PCR amplicons of the selected bacterial isolates using their genomic DNA as a template for PCR with the primers for 16S rDNA (A). Molecular phylogenetic analyses of Stenotrophomonas maltophilia (B) and Bacillus koreensis $(\mathbf{C})$ by the maximum likelihood model in the MEGA 7.0 package.

3.3. Bioprocess Optimization of TDS Productivity of B. koreensis and S. maltophilia by Response Surface Methodology

Nineteen independent variables, namely yeast extract, peptone, phenylalanine, tyrosine, tryptophan, glycine, valine, methionine, asparagine, cysteine, glutamic acid, beef extract, sucrose, glucose, xylose, $\mathrm{NaCl}$, ammonium nitrate, incubation time, and $\mathrm{pH}$, were screened for TDS productivity by the potent bacteria isolates using a Plackett-Burman design (Table 1). The matrix of the Plackett-Burman design with the significance of the independent variables affecting TDS productivity by $B$. koreensis with the predicted and actual values shown in Table 2 . The fluctuation of the predicted TDS yield that had been resolved from the Plackett-Burman design ranged from 2.2 to $18.0 \mu \mathrm{mol} / \mathrm{mg} / \mathrm{min}$, reflecting the significance of the optimization process and the efficiency of the Plackett-Burman design. The maximum TDS actual activity by B. koreensis $(18 \mu \mathrm{mol} / \mathrm{mg} / \mathrm{min})$ was obtained in the presence sucrose $(1 \mathrm{~g})$, peptone $(5 \mathrm{~g})$, ammonium nitrate $(4 \mathrm{~g})$, tryptophan $(1 \mathrm{~g})$, tyrosine $(1 \mathrm{~g})$, glucose $(1 \mathrm{~g})$, glutamic acid $(1 \mathrm{~g})$, glycine $(1 \mathrm{~g})$, and methionine $(4 \mathrm{~g})$ per liter of distilled water, at a $\mathrm{pH} 6.0$, and after 6 days of icubation. 
Table 1. Experimental independent variables at two levels used for TDS production by the PlackettBurman design.

\begin{tabular}{|c|c|c|c|}
\hline \multirow{2}{*}{ Code } & \multirow{2}{*}{ Variables } & \multicolumn{2}{|c|}{ Level } \\
\hline & & -1 & 1 \\
\hline $\mathrm{X} 1$ & Yeast extract $(\mathrm{g} / \mathrm{L})$ & 1 & 4 \\
\hline $\mathrm{X} 2$ & Peptone (g/L) & 1 & 5 \\
\hline $\mathrm{X} 3$ & Phenylalanine (g/L) & 1 & 4 \\
\hline $\mathrm{X} 4$ & Tyrosine (g/L) & 1 & 4 \\
\hline $\mathrm{X} 5$ & Tryptophan (g/L) & 1 & 4 \\
\hline $\mathrm{X} 6$ & Glycine (g/L) & 1 & 4 \\
\hline$X 7$ & Valine $(\mathrm{g} / \mathrm{L})$ & 1 & 4 \\
\hline $\mathrm{X} 8$ & Methionine (g/L) & 1 & 4 \\
\hline X9 & Asparagine (g/L) & 1 & 4 \\
\hline $\mathrm{X} 10$ & Cysteine (g/L) & 1 & 4 \\
\hline $\mathrm{X} 11$ & Glutamic acid (g/L) & 1 & 4 \\
\hline $\mathrm{X} 12$ & Beef extract (g/L) & 1 & 4 \\
\hline $\mathrm{X} 13$ & Sucrose (g/L) & 1 & 5 \\
\hline $\mathrm{X} 14$ & Glucose (g/L) & 1 & 5 \\
\hline $\mathrm{X} 15$ & Xylose, (g/L) & 1 & 5 \\
\hline $\mathrm{X} 16$ & $\mathrm{NaCl}(\mathrm{g} / \mathrm{L})$ & 2 & 6 \\
\hline $\mathrm{X} 17$ & Ammonium nitrate $(\mathrm{g} / \mathrm{L})$ & 1 & 4 \\
\hline $\mathrm{X} 18$ & $\mathrm{pH}$ & 6 & 8 \\
\hline $\mathrm{X} 19$ & Incubation period (day) & 3 & 6 \\
\hline
\end{tabular}

The correlation between TDS productivity by B. koreensis and the independent variables was assessed through the multiple-regression statistical analysis of variance (ANOVA) of the experimental design. The significance of the tested variables on the production of TDS by the bacterial isolate was clearly shown with a Pareto Chart, a probability plot of the independent variables, which showed the actual and predicted TDS productivity (Figure S1). The significance of each coefficient was determined from the $p$-value and student's $t$-test. From the normal probability plot, the points of the residuals were arranged near the diagonal line, revealing the independent normal distribution of the variables, ensuring the perfect fitting of the expected TDS productivity. From the ANOVA analysis of the Plackett-Burman design, the constructed model was highly significant, which was revealed values of Fisher's F-test value of 7.4 and the lower probability $p$-value of 0.029. Thus, upon using the Plackett-Burman design, the TDS productivity of $B$. koreensis increased from 8.8 to $18.1 \mu \mathrm{mol} / \mathrm{mg} / \mathrm{min}$, i.e., a 2.1-fold increase.

\subsection{Purification, and Molecular Subunit Structure of TDS from S. maltophilia and B. koreensis}

Taxadiene synthase was purified from the potent bacterial isolates $S$. maltophilia and B. koreensis, which were grown on the nutritionally optimized medium from the response surface methodology designs. After incubation, the bacteria cells were pelleted, and the intracellular proteins were extracted, and the TDS was purified by the size-exclusion and ion-exchange chromatographic approaches [40-42,47]. The protein fractions were eluted from the columns, and the TDS activity and concentration were determined by the standard assay. Apparently, the active TDS fractions from both chromatographic approaches displayed relative proximity in terms of their molecular mass and overall charge (Figure 4). The overall purification profile of both of the bacterial isolates is shown in 
Table 3. When the gel-filtration step was used, the TDS activity from B. koreensis and $S$. maltophilia increased by 2.9 - and 10.6-fold, while when using ion-exchange chromatography, the enzyme activity increased by about 15.9- and 14.6-fold, respectively. By the last purification, the specific activity of the purified TDS in B. koreensis and S. maltophilia was $6.84 \mu \mathrm{mol} / \mathrm{mg} / \mathrm{min}$ and $1.7 \mu \mathrm{mol} / \mathrm{mg} / \mathrm{min}$, respectively. The overall purification yields of TDS from both of the bacterial isolates were 19.2 and $16.9 \%$, respectively.

Table 2. The twenty-trial Plackett-Burman experimental design for evaluation of the independent variables with coded values along with the observed TDS production by B. koreensis. The " -1 " sign corresponds to the minimum value, and the " +1 " sign corresponds to the maximum value of the input parameter range.

\begin{tabular}{|c|c|c|c|c|c|c|c|c|c|c|c|c|c|c|c|c|c|c|c|c|c|}
\hline $\mathrm{g} / \mathrm{L}$ & 1 & 2 & 3 & 4 & 5 & 6 & 7 & 8 & 9 & 10 & 11 & 12 & 13 & 14 & 15 & 16 & 17 & 18 & 19 & & \\
\hline Run & X1 & $\mathrm{X} 2$ & X3 & $X 4$ & X5 & X6 & X7 & X8 & X9 & X10 & X11 & X12 & X13 & X14 & X15 & x16 & X17 & X18 & X19 & \multicolumn{2}{|c|}{$\begin{array}{l}\text { Predicted } \\
\text { TDS Activity }\end{array}$} \\
\hline 1 & -1 & -1 & -1 & -1 & 1 & 1 & -1 & 1 & 1 & -1 & -1 & 1 & 1 & 1 & 1 & -1 & 1 & -1 & 1 & 2.26 & 3.465 \\
\hline 2 & 1 & 1 & 1 & -1 & 1 & -1 & 1 & -1 & -1 & -1 & -1 & 1 & 1 & -1 & 1 & 1 & -1 & -1 & 1 & 1.8 & 2.85 \\
\hline 3 & 1 & 1 & -1 & 1 & 1 & -1 & -1 & 1 & 1 & 1 & 1 & -1 & 1 & -1 & 1 & -1 & -1 & -1 & -1 & 2.27 & 3.55 \\
\hline 4 & 1 & -1 & 1 & -1 & 1 & -1 & -1 & -1 & -1 & 1 & 1 & -1 & 1 & 1 & -1 & -1 & 1 & 1 & 1 & 3.78 & 5.85 \\
\hline 5 & -1 & -1 & 1 & 1 & -1 & 1 & 1 & -1 & -1 & 1 & 1 & 1 & 1 & -1 & 1 & -1 & 1 & -1 & -1 & 0.8 & 1.25 \\
\hline 6 & -1 & -1 & -1 & -1 & -1 & -1 & -1 & -1 & -1 & -1 & -1 & -1 & -1 & -1 & -1 & -1 & -1 & -1 & -1 & 6.98 & 10.92 \\
\hline 7 & -1 & 1 & 1 & -1 & -1 & 1 & 1 & 1 & 1 & -1 & 1 & -1 & 1 & -1 & -1 & -1 & -1 & 1 & 1 & 6.78 & 10.52 \\
\hline 8 & 1 & 1 & 1 & 1 & -1 & 1 & -1 & 1 & -1 & -1 & -1 & -1 & 1 & 1 & -1 & 1 & 1 & -1 & -1 & 6.09 & 9.55 \\
\hline 9 & -1 & 1 & 1 & 1 & 1 & -1 & 1 & -1 & 1 & -1 & -1 & -1 & -1 & 1 & 1 & -1 & 1 & 1 & -1 & 7.08 & 10.95 \\
\hline 10 & -1 & -1 & 1 & 1 & 1 & 1 & -1 & 1 & -1 & 1 & -1 & -1 & -1 & -1 & 1 & 1 & -1 & 1 & 1 & 5.60 & 8.765 \\
\hline 11 & 1 & -1 & 1 & 1 & -1 & -1 & 1 & 1 & 1 & 1 & -1 & 1 & -1 & 1 & -1 & -1 & -1 & -1 & 1 & 5.03 & 7.86 \\
\hline 12 & 1 & -1 & -1 & -1 & -1 & 1 & 1 & -1 & 1 & 1 & -1 & -1 & 1 & 1 & 1 & 1 & -1 & 1 & -1 & 5.67 & 8.85 \\
\hline 13 & -1 & 1 & 1 & -1 & 1 & 1 & -1 & -1 & 1 & 1 & 1 & 1 & -1 & 1 & -1 & 1 & -1 & -1 & -1 & 2.58 & 3.95 \\
\hline 14 & 1 & -1 & 1 & -1 & -1 & -1 & -1 & 1 & 1 & -1 & 1 & 1 & -1 & -1 & 1 & 1 & 1 & 1 & -1 & 11.72 & 18.3 \\
\hline 15 & -1 & -1 & -1 & 1 & 1 & -1 & 1 & 1 & -1 & -1 & 1 & 1 & 1 & 1 & -1 & 1 & -1 & 1 & -1 & 2.12 & 3.3 \\
\hline 16 & -1 & -1 & -1 & 1 & 1 & 1 & 1 & -1 & 1 & -1 & 1 & -1 & -1 & -1 & 1 & 1 & 1 & -1 & 1 & 1.18 & 1.75 \\
\hline 17 & 1 & 1 & -1 & 1 & -1 & 1 & -1 & -1 & -1 & -1 & 1 & 1 & -1 & 1 & 1 & -1 & -1 & 1 & 1 & 4.07 & 6.35 \\
\hline 18 & -1 & 1 & -1 & -1 & -1 & -1 & 1 & 1 & -1 & 1 & 1 & -1 & -1 & 1 & 1 & 1 & 1 & -1 & 1 & 5.56 & 8.68 \\
\hline 19 & -1 & 1 & -1 & 1 & -1 & -1 & -1 & -1 & 1 & 1 & -1 & 1 & 1 & -1 & -1 & 1 & 1 & 1 & 1 & 6.56 & 10.25 \\
\hline 20 & 1 & 1 & -1 & -1 & 1 & 1 & 1 & 1 & -1 & 1 & -1 & 1 & -1 & -1 & -1 & -1 & 1 & 1 & -1 & 10.46 & 16.35 \\
\hline
\end{tabular}

Table 3. Purification profile of TDS from B. koreensis and S. maltophilia.

\begin{tabular}{|c|c|c|c|c|c|c|c|c|c|c|}
\hline \multirow[b]{2}{*}{ Step } & \multicolumn{5}{|c|}{ B. koreensis } & \multicolumn{5}{|c|}{ S. maltophilia } \\
\hline & $\begin{array}{l}\text { Total } \\
\text { Protein } \\
\text { (mg) }\end{array}$ & $\begin{array}{c}\text { Total } \\
\text { Activity } \\
(\mu \mathrm{mol} / \mathrm{min})\end{array}$ & $\begin{array}{c}\text { Specific } \\
\text { Activity } \\
(\mu \mathrm{mol} / \mathrm{mg} / \mathrm{min})\end{array}$ & $\begin{array}{l}\text { Yield } \\
(\%)\end{array}$ & $\begin{array}{l}\text { Purification } \\
\text { Fold }\end{array}$ & $\begin{array}{l}\text { Total } \\
\text { Protein } \\
\text { (mg) }\end{array}$ & $\begin{array}{c}\text { Total } \\
\text { Activity } \\
(\mu \mathrm{mol} / \mathrm{min})\end{array}$ & $\begin{array}{c}\text { Specific } \\
\text { Activity } \\
\text { ( } \mu \mathrm{mol} / \mathrm{mg} / \mathrm{min})\end{array}$ & $\begin{array}{l}\text { Yield } \\
(\%)\end{array}$ & $\begin{array}{l}\text { Purification } \\
\text { Fold }\end{array}$ \\
\hline Crude enzyme & 413.6 & 177.6 & 0.43 & 100 & 1 & 650 & 78.2 & 0.13 & 100 & 1 \\
\hline Acetone precipitate & 87.5 & 60.9 & 0.7 & 34.3 & 1.6 & 586 & 39.5 & 0.54 & 52.6 & 4.48 \\
\hline Sephadex-G $\mathrm{G}_{200}$ & 32.3 & 40.6 & 1.26 & 22.9 & 2.9 & 23.9 & 30.5 & 1.29 & 50.0 & 10.6 \\
\hline DEAE-Sepharose & 0.5 & 3.42 & 6.84 & 19.2 & 15.9 & 5.6 & 9.8 & 1.7 & 16.9 & 14.6 \\
\hline
\end{tabular}

The molecular homogeneity of the active TDS fractions was checked, and the most homogenous molecular fractions were gathered and concentrated prior to the next purification step. The entire molecular mass and molecular subunit structures of the purified TDS from both bacterial isolates were determined from the native-PAGE and SDS-PAGE analyses (Figure 4). From the native-PAGE, the entire molecular mass of the purified TDS from both of the bacterial isolates displayed approximately $180 \mathrm{kDa}$. Under denaturing conditions, the purified TDS from B. koreensis and S. maltophilia were recorded to be 65 and 
$80 \mathrm{kDa}$, respectively. From the native and SDS-PAGE, the purified TDS from the bacterial isolates had two identical subunits, meaning that it had a homodimeric identity.

A
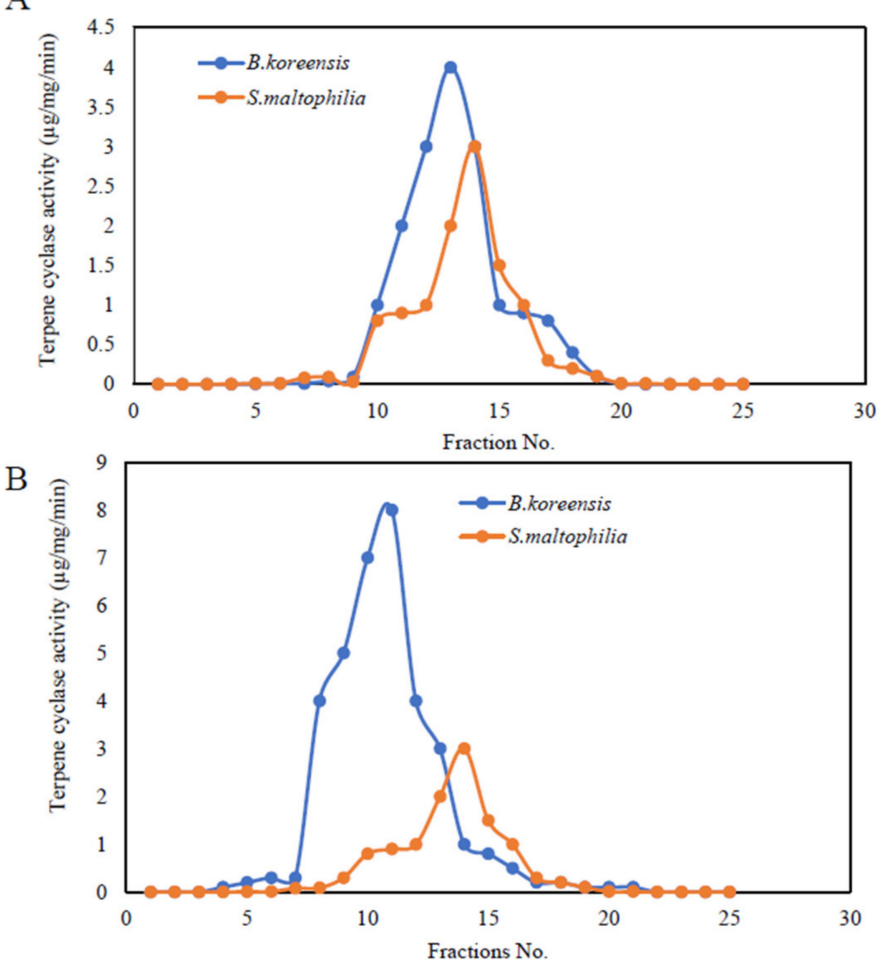

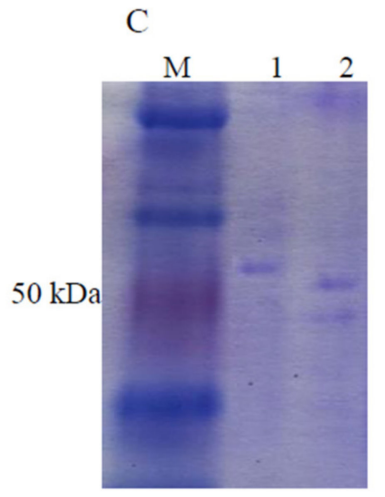

$\mathrm{D}$ M 12

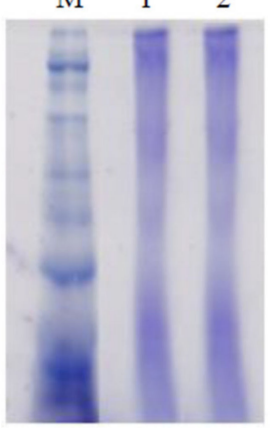

Figure 4. Purification and molecular subunit structure of TDS from S. maltophilia and B. koreensis. The bacterial pellets were pulverized in liquid nitrogen and were dispensed in Tris- $\mathrm{HCl}$ buffer with protease inhibitors, as described in the Materials and Methods sections. TDS activity resulting from the ion-exchange (A) and gel-filtration (B) chromatographic approaches for both bacterial isolates. The SDS-PAGE profile showing the molecular subunit structure of purified TDS (C) and native-PAGE displaying the entire molecular mass of TDS (D) from both bacterial isolates. The numbers 1 and 2 on the gels refer to Bacillus koreensis and S. maltophilia, respectively. M is the protein ladder (Blue Plus Protein Maker, Cat. \# DM101, 14-100 kDa).

\subsection{The Biochemical Properties of Purified TDS from Both Bacterial Isolates}

The biochemical properties of the purified TDS from B. koreensis and S. maltophilia such as reaction temperature, thermal stability, reaction $\mathrm{pH}$, and $\mathrm{pH}$ stability were determined. The influence of the reaction temperature on the TDS activity was determined by incubation at $10,20,30,37,45$, and $50^{\circ} \mathrm{C}$, after which, the enzymatic activity was measured. A gradual increase in the enzymatic activity was noticed to correlate with the reaction temperature. The maximum TDS activity by both of the bacterial isolates was recorded at $\sim 40{ }^{\circ} \mathrm{C}$, with a significant reduction to their activity at $50{ }^{\circ} \mathrm{C}$ (Figure 5). The upper panel of Figure 6 shows how the released taxadiene byproducts appeared on the plates. The enzymes from both bacterial isolates produced the same reactivity pattern to the reaction temperature. At the $40{ }^{\circ} \mathrm{C}$ reaction temperature, the TDS activity from B. koreensis and S. maltophilia were $8.1 \mu \mathrm{mol} / \mathrm{mg} / \mathrm{min}$ and $2.5 \mu \mathrm{mol} / \mathrm{mg} / \mathrm{min}$, respectively. 

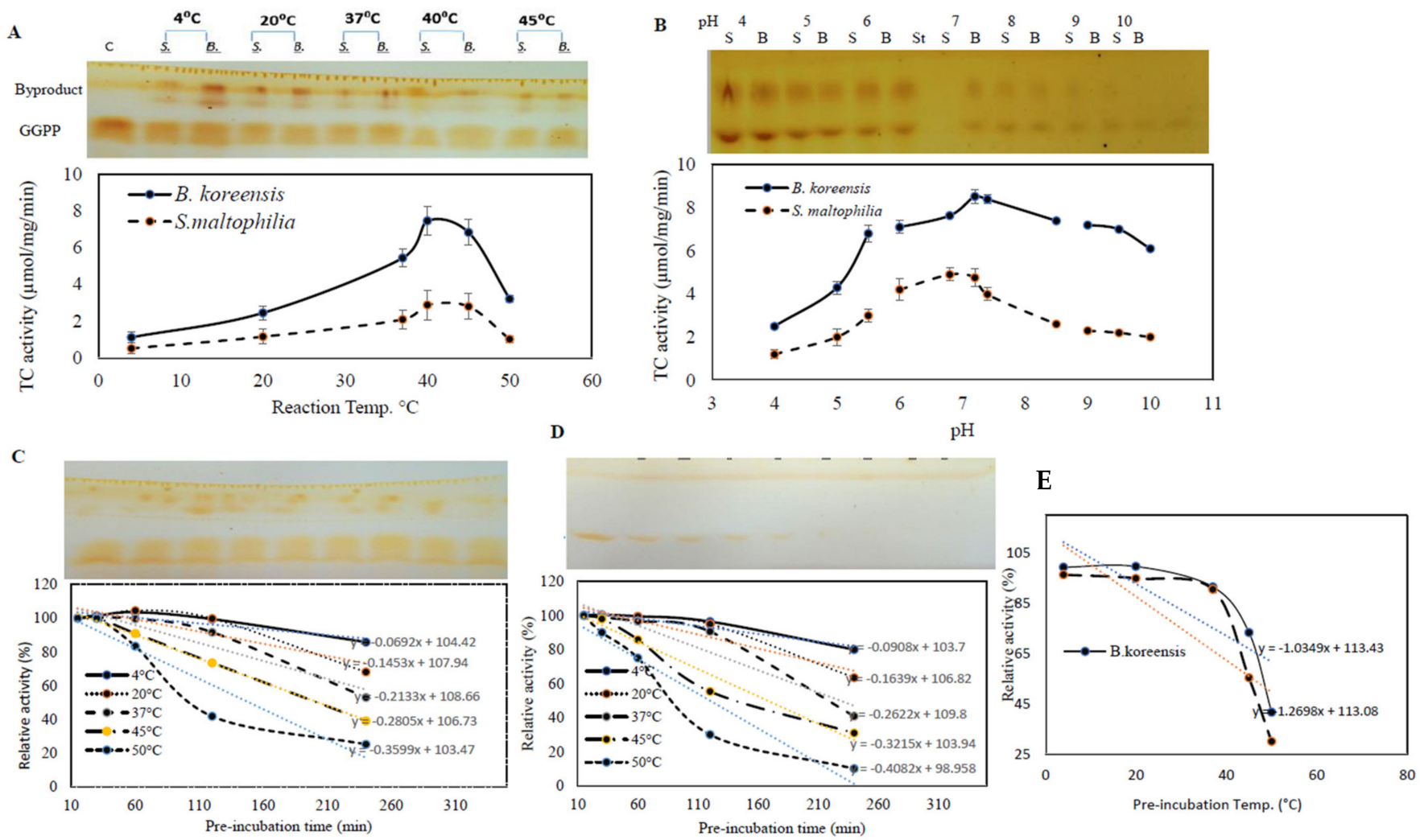

Figure 5. Biochemical properties of TDS from S. maltophilia and B. koreensis. The effect of reaction temperature (A), reaction $\mathrm{pH}(\mathbf{B})$, thermal stability profiles of B. koreensis (C), and S. maltophilia (D). For each assay, the TLC chromatogram of the residual GGPP is placed in the upper panel, while the actual activity of TDS is in the lower panel. (E), Profile of half-life temperature (Tm) of purified TDS of S. maltophilia and B. koreensis.
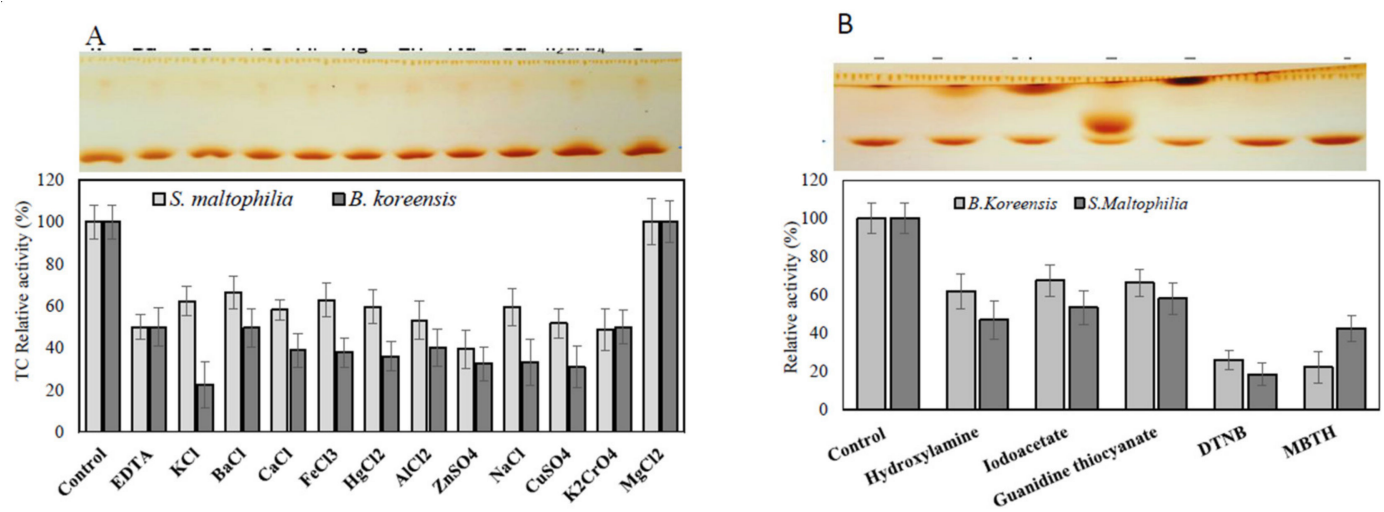

Figure 6. Effect of cation inhibitors and amino acid suicide analogues on the purified TDS from S. maltophilia and B. koreensis. The purified TDS from both bacterial isolates were dialyzed with EDTA, apo-enzyme was concentrated and amended with different inhibitors, and the residual activity of the enzymes was determined by the standard assay as described in the Materials and Methods section. The TLC chromatogram of the TDS reaction mixture is in the upper panel, and the actual activity is in the lower panel. The TDS activity in response to cation inhibitors (A) and various active-site amino acid suicide analogues (B).

The effect of the reaction mixture $\mathrm{pH}$ on the activities of the purified TDS from the experimented bacterial isolates was assessed in the $\mathrm{pH}$ range of 4-10 using different buffers. The maximum TDS activity for TDS from B. koreensis and S. maltophilia was reported at $\mathrm{pH}$ 7.4. A dramatic decrease in the enzymatic activity of about $75 \%$ was measured in acidic conditions ( $\mathrm{pH} 4.0$ ), this was in contrast to the enzymatic activity being quite stable at slightly alkaline $\mathrm{pHs}(\mathrm{pH} 10.0)$. 
The effect of the thermal stability of purified TDS from both bacterial isolates was assessed by preincubating the enzyme without substrate and then measuring the residual enzymatic activity using the standard assay. From the thermal stability profile, the catalytic structure of the purified enzyme was dramatically reduced with the preincubation of the enzyme at a higher temperature (Figure 5), as revealed from the thermal stability parameters (Table 4$)$. At $4{ }^{\circ} \mathrm{C}$, the half-life time $\left(T_{1 / 2}\right)$ of the TDS from $B$. koreensis and S. maltophilia was $136.0 \mathrm{~h}$ and $98 \mathrm{~h}$, respectively, while at $37^{\circ} \mathrm{C}$, the half-life time $\left(T_{1 / 2}\right)$ was $46.0 \mathrm{~h}$ and $48.0 \mathrm{~h}$ for the purified TDS from B. koreensis and S. maltophilia, respectively. The half-life temperature $\left(T_{m}\right)$ for the TDS from B. koreensis and S. maltophilia was 61.3 and $49.7^{\circ} \mathrm{C}$, respectively. The purified TDS from $B$. koreensis displayed relatively better thermal and catalytic stability than $S$. maltophilia, as revealed from the thermal inactivation rate at $37^{\circ} \mathrm{C}$, showing values of $0.15 \times 10^{-3}$ and $0.24 \times 10^{-3}$, respectively. The taxadiene that was released TDS as a byproduct and that consumed GGPP is shown as it appeared on the TLC plate in the upper panel of Figure 5. Thus, from the thermal stability kinetics and the molecular subunit structure, the purified TDS from both bacterial isolates displayed slightly structural/conformational differences.

Table 4. Thermal kinetic parameters of TDS from B. koreensis and S. maltophilia.

\begin{tabular}{|c|c|c|c|c|c|c|}
\hline \multirow{2}{*}{${ }^{\circ} \mathrm{C}$} & \multicolumn{3}{|c|}{ B. koreensis } & \multicolumn{3}{|c|}{ S. maltophilia } \\
\hline & $T_{1 / 2}(\mathrm{~h}) *$ & $K r(\min ) * *$ & $T_{m}\left({ }^{\circ} \mathrm{C}\right) * * *$ & $T_{1 / 2}(\mathrm{~h}) *$ & $K r(\min ) * *$ & $T_{m}\left({ }^{\circ} \mathrm{C}\right) * * *$ \\
\hline 4 & 136.0 & $0.02 \times 10^{-3}$ & \multirow{5}{*}{61.3} & 98 & $0.03 \times 10^{-3}$ & \multirow{5}{*}{49.7} \\
\hline 20 & 66.4 & $0.1 \times 10^{-3}$ & & 68 & $0.14 \times 10^{-3}$ & \\
\hline 37 & 46 & $0.15 \times 10^{-3}$ & & 48 & $0.24 \times 10^{-3}$ & \\
\hline 45 & 23 & $0.24 \times 10^{-3}$ & & 24 & $0.30 \times 10^{-3}$ & \\
\hline 50 & 10 & $0.29 \times 10^{-3}$ & & 11 & $0.32 \times 10^{-3}$ & \\
\hline
\end{tabular}

* Half-life time $\left(T_{1 / 2}\right)$ was expressed by the time in which the enzyme retained $50 \%$ of its initial activity by preheating it without substrate at each temperature degree. ${ }^{* *} \ln (\mathrm{At} / \mathrm{A} 0)=-\mathrm{Kr} T_{m}$, where A0 and At are the specific TDS activity at zero and $t$ time. ${ }^{* * *}$ Thermal denaturation rate $(K r)$ was expressed by the logarithmic decreasing of enzyme activity with the time at each temperature, as defined from the first-order kinetic model.

\subsection{Effect of Inhibitors and Amino Acid Suicide Analogues on the Activity of TDS}

The active sites and structural identities of the purified TDS from both bacterial isolates in response to various inhibitors and amino acid suicide analogues were estimated. The purified enzyme preparations were demetallized, and then the apoenzyme were amended with different inhibitors for $2 \mathrm{~h}$ at $4{ }^{\circ} \mathrm{C}$, and the residual activity was measured by the standard assay. From the results (Figure 6), the purified Apo-TDS from both bacterial isolates lost about $50 \%$ of their initial activity upon demetallization, ensuring the metalloproteinic identity of this enzyme. The activity of the purified TDS was restored completely upon the addition of $\mathrm{Mg}^{2+}$, confirming the identity of this enzyme on $\mathrm{Mg}^{2+}$ as a cofactor. However, the activity of the purified enzyme was slightly inhibited upon the addition of other metals cations compared to Apo-TDS enzyme preparation. These results reveal the dependence of purified TDS on the $\mathrm{Mg}^{2+}$ essential cofactor. The taxadiene that was released as an enzymatic byproduct from the purified TDS is shown as it appeared on the TLC plate (upper panel, Figure 6). The active sites and allosteric sites of the purified TDS were mapped using different amino acid analogues [40-42,47,50-52]. The activity of the purified TDS from both bacterial isolates was dramatically reduced by about 60 and 50\% upon the addition of DTNB and MBTH, respectively (Figure 6), ensuring the implementation of reactive thiols and ammonia groups on the active site domains of the purified TDS. The TDS activity from both bacterial sources was slightly reduced by about $20-25 \%$ in response to hydroxylamine, iodoacetate, and guanidine thiocyanate compared to the control enzymes. 


\section{Discussion}

Taxadiene synthase is the committed rate-limiting enzyme of Taxol biosynthesis by the cyclization of GGPP into taxadiene that has been previously characterized in Taxus brevifolia $[2,4]$. Taxol-producing potency from endophytic fungi has been frequently reported $[5,6,9,10,16,18,19]$; however, the attenuation/loss of the fungal biosynthetic potency of Taxol is the major challenge that is preventing the ongoing industrial implementation of this approach. Several hypotheses have been proposed to unravel the physiological and metabolic vagueness of the attenuation of the fungal biosynthetic potency of Taxol, as extensively reported by several studies $[11,13,53,54]$. Among these metabolic traits, the dependence of the biosynthetic machinery of Taxol by fungi on the external signals from the surrounding microbiome is the most authenticated factor $[9,19,55,56]$. Triggering the expression and functionality of TDS as the rate limiting enzyme of Taxol biosynthesis is one the most noticeable metabolic criterion in response to the cocultivation with different Taxoleliciting bacteria $[55,57]$. Thus, the characterization and subsequent overexpression of this enzyme on Taxol-producing fungal isolates could emphasize and stabilize the biosynthetic potency of Taxol by potent fungal isolates. As such, this study provides motivation for the further exploration of the taxadiene synthase/diterpene cyclase with robust catalytic efficiency and turnover number from different bacterial isolates.

Twenty-three endophytic bacterial isolates were recovered from the leaves of $M$. piperita L., Coriandrum sativum L., A. graveolens L., M. oleifera Lam., and P. gracilior. Among the recovered bacteria, the highest TDS productivity were determined with $B$. koreensis and S. maltophilia, which were been identified based on their $16 \mathrm{~S}$ rDNA sequence and deposited on genbank with the accession \# MN592666.1 and MN592660, respectively. The chemical identity of the released putative taxadiene as an enzymatic byproduct of purified TDS" was confirmed in the GC-MS analysis, as it produced the same fragmentation pattern as the parent and daughter molecules of authentic taxadiene. Although, the catalytic identity of the purified terpene cyclase is the same as the taxadiene synthase from the target bacterial isolates, these bacterial isolates lack the ability to naturally produce taxadiene and Taxol. The molecular mass of the taxadiene parent molecule is $271.2 \mathrm{~m} / \mathrm{z}$ compared to that of authentic taxadiene, which is $272.1 \mathrm{~m} / z$ [3,27]. Interestingly, this is the first report exploring taxadiene production from these bacterial isolates. However, different types of terpenoids have frequently been reported to be produced from certain filamentous bacteria [58], such as from Cyanobacteria [59] and Myxobacteria [60] and fungal isolates [5,9,46]. Among the different types of bacteria, filamentous ones "Actinomycetes" are the superior terpenoids for the production of prokaryotes, as extensively reviewed [20,23,60,61]. Unlike the uncountable number of terpenoids from bacteria [20], this is the first study exploring Taxadiene biosynthesis from bacteria. Nevertheless, the metabolic engineering of B. subtilis for taxadiene synthesis, "the first committed step in Taxol production", was conducted by expressing the plant-derived taxadiene synthase and other enzymes that are able to increase the flux of GGPP precursors [27]. Intriguingly, this is the first study to explore the natural production of taxadiene from B. koreensis and S. maltophilia, which could provide a novel strategy for commercial Taxol production $[6,9,19]$.

To validate TDS activity and taxadiene productivity, the $t d s$ gene was amplified by PCR with the nested primers that were designed based on the conserved active-site sequences of TDS from different fungal and plant sources (Taxus brevifolia and T. baccata) $[6,9,19]$. The active sites of the $t d s$ genes exhibited a highly conserved aspartate-rich motif DDXX $(X)(D, E)$ and an NSE triad ND(L,I,V)XSXXXE that were involved in $\mathrm{Mg}^{2+}$ cofactor binding [62]. The amplicons of $t d s 1$ and $t d s 2$ from both bacterial isolates B. koreensis and S. maltophilia were sequenced and analyzed using the BLAST alignment tool from NCBI. From the alignment profile, the partial sequence of the putative $t d s$ of $B$. koreensis displayed $90-99 \%$ similarity with the $t d s$ of T. brevifolia and T. baccata and A. flavipes [61]. The PCR screening of the $t d s$ and $d b a t$ signature genes, "rate-limiting enzymes of Taxol biosynthesis", were independently authenticated i for different microbes [63-66]. 
The productivity of the taxadiene synthase by B. koreensis and S. maltophilia was nutritionally optimized with the surface response methodology using nineteen independent variables. Upon using the Plackett-Burman design, the TDS activity increased from 2.2 to $18.0 \mu \mathrm{mol} / \mathrm{mg} / \mathrm{min}$, reflecting the significance of the independent variables. The maximum TDS activity achieved by B. koreensis was obtained in presence sucrose (1 g), peptone (5 g), ammonium nitrate $(4 \mathrm{~g})$, tryptophan $(1 \mathrm{~g})$, tyrosine $(1 \mathrm{~g})$, glucose $(1 \mathrm{~g})$, glutamic acid $(1 \mathrm{~g})$, glycine $(1 \mathrm{~g})$, and methionine $(4 \mathrm{~g})$ per liter of distilled water, at $\mathrm{pH}$ 6.0, and after 6 days of incubation. The correlation of TDS productivity with the independent variables was assessed by the multiple-regression statistical analysis of variance (ANOVA) of the experimental design, as revealed from the $p$-value and student's $t$-test. Thus, upon using the Plackett-Burman design, the TDS productivity achieved by B. koreensis increased by about 2.1-fold. Similar results were reported when optimizing the productivity of the microbial enzymes upon nutritional optimization [35,39].

The enzymes were purified using the gel-filtration and ion-exchange chromatographic approaches to determine its molecular homogeneity, which was confirmed by SDS-PAGE. The purified TDS from both of the bacterial isolates displayed a relative proximity on their molecular mass and overall charge. The activity of the TDS from B. koreensis and S. maltophilia increased by about 15.9- and 14.6- folds, respectively, upon the use of this purification protocol. The entire molecular mass of the purified TDSs from both of the bacterial isolates was approximately $180 \mathrm{kDa}$ on native-PAGE, while the TDS subunit structure from B. koreensis and S. maltophilia were 65 and $80 \mathrm{kDa}$, respectively, under denaturing-PAGE $[3,31]$. The purified TDS from the bacterial isolates had two identical subunits with a homodimeric identity, which was consistent with the overexpressed TDS achieved by the T. baccata in B. subtilis [24,27].

The biochemical and kinetic properties of the purified TDSs were determined. The maximum activity of the TDS from both bacterial isolates was recorded at $37-40{ }^{\circ} \mathrm{C}$. At $4{ }^{\circ} \mathrm{C}$, the half-life time $\left(T_{1 / 2}\right)$ of TDS from B. koreensis and S. maltophilia was $136.0 \mathrm{~h}$ and $98 \mathrm{~h}$, respectively. The half-life temperature $\left(T_{m}\right)$ for the purified TDS from $B$. koreensis and $S$. maltophilia was 61.3 and $49.7^{\circ} \mathrm{C}$, respectively, ensuring the slight thermal stability of TDS produced from $B$. koreensis than $S$. maltophilia. This is partially consistent with the highest activity achieved by T. baccata, where TDS was reported at $20^{\circ} \mathrm{C}$, with no activity at $37^{\circ} \mathrm{C}$ [27], revealing the significant thermal stability of purified the TDS produced by $B$. koreensis and S. maltophilia. This obvious catalytic efficiency and stability could be related to the amino acid sequence domains and tertiary structure of the TDS produced from these bacterial isolates during posttranslational modification since the TDS from T. baccata is naturally expressed as a pseudo-mature enzyme of 862 amino acids with splicing of 60 amino acids as a plastidal signal sequence during the maturation process [67]. Thus, the thermal stability of TDS produced from B. koreensis and S. maltophilia is better than TDS produced from different plant sources, making it a feasible/unique biochemical criterion. Further molecular modelling and crystal structure studies aiming to resolve the molecular structure of the current TDS compared to TDS from T. baccata are ongoing.

The maximum TDS activity for TDS from B. koreensis and S. maltophilia was reported at $\mathrm{pH}$ 7.4-8.0. A dramatic decrease to the enzymatic activity by about $75 \%$ was measured at acidic conditions ( $\mathrm{pH} 4.0$ ), which is unlike the quite good enzymatic activity stability seen at slightly alkaline $\mathrm{pHs}(\mathrm{pH}$ 10.0). Similar results were reported for TDS from T. baccata [68] and T. canadensis [69].

The active sites and structural identities of purified TDS from both bacterial isolates in response to various inhibitors and amino acid suicide analogues were mapped. ApoTDSs retained $\sim 50 \%$ of the initial activities of holo-TDS, ensuring the metalloproteinic identity of this enzyme. The activity of purified TDS was completely restored upon the addition of $\mathrm{Mg}^{2+}$, confirming the identity of this enzyme on $\mathrm{Mg}^{2+}$ as a cofactor $[57,68]$. However, the activity of the purified enzyme was slightly inhibited upon the addition of other metals cations compared to Apo-TDS enzyme preparation. The purified TDS activity was dramatically reduced by upon the addition of DTNB and MBTH, respectively, 
ensuring the implementation of reactive thiols and ammonia groups on their active site domains [41-43,45,49,50,52,70,71]. Similar studies ensure the metalloproteinic identity of TDS from T. brevifolia and T. baccata [3,57,69].

In conclusion, taxadiene synthase was purified from B. koreensis and S. maltophilia, which had higher catalytic efficiency to cyclize GGPP into taxadiene as the rate limiting step in Taxol biosynthesis. The chemical identity of taxadiene was authenticated from the GCMS analysis by comparing it to the authentic one. In addition to the colorimetric activities of TDS, the active site domains of $t d s$ were amplified by PCR, which were sequenced and displayed more similarity to those from T. baccata and T. brevifolia. Although the subunit structure and metalloproteinic of TDS of B. koreensis and S. maltophilia was similar to that of the T. baccata TDS, the purified enzyme displayed plausibly higher thermal stability and catalytic efficiency. This is the first report describing TDS from bacteria with a higher affinity to cyclize GGPP into taxadiene as a rate-limiting step in Taxol biosynthesis; thus, furthering the overexpression analysis of TDS on fungi could be a new strategy for sustaining the biosynthetic machinery of Taxol in the target fungi.

Supplementary Materials: The following are available online at https: / www.mdpi.com/article/ 10.3390 /scipharm89040048/s1.

Author Contributions: A.S.A.E.-S. conceptualized the work; M.F. and M.S. designed the work; A.S.A.E.-S. wrote the manuscript; A.M.R. conducted the statistical analysis; A.F.E.-B. completed the factorial design optimization analysis; A.F.E.-B. and A.A.S. revised the manuscript; Y.M. performed the experimental work; B.S. edited the manuscript. All authors have read and agreed to the published version of the manuscript.

Funding: We appreciate the financial support from the Academy of Scientific Research and Technology, Egypt, to Ashraf S.A. El-Sayed and the support from the Medical Faculty of Umea University, the Council of Vasterbotten, and Lions Cancer Research Fund to Basel Sitohy.

Institutional Review Board Statement: Not applicable.

Data Availability Statement: All data generated during this study are included in the article.

Acknowledgments: We appreciate the financial support from the Egyptian Academy of Scientific Research and Technology (ASRT) to A.S.A.E. All the authors have consented to the acknowledgment.

Conflicts of Interest: The authors declare that they have no conflict interests.

\section{References}

1. Suffness, M. Taxol: Science and Applications; CRC Press: Boca Raton, FL, USA, 1995; ISBN 9780849383823.

2. Wani, M.C.; Taylor, H.L.; Wall, M.E.; Coggon, P.; McPhail, A.T. Plant Antitumor Agents. VI. The Isolation and Strcture of Taxol, a Novel Antileukemic and Antitumo Agent from Taxus bretvifolia. J. Am. Chem. Soc. 1971, 19, 2325-2327. [CrossRef]

3. Hezari, M.; Lewis, N.G.; Croteau, R. Purification and Characterization of Taxa-4(5),11(12)-diene Synthase from Pacific Yew (Taxus Brevifolia) that Catalyzes the First Committed Step of Taxol Biosynthesis. Archiv. Biochem. Biophys. 1995, 322, 437-444. [CrossRef] [PubMed]

4. Schiff, P.B.; Fant, J.; Horwitz, S.B. Promotion of microtubule assembly in vitro by taxol. Nature 1979, 277, 665-667. [CrossRef]

5. El-Sayed, A.S.A.; El-Sayed, M.T.; Rady, A.M.; Zein, N.; Enan, G.; Shindia, A.; El-Hefnawy, S.; Sitohy, M.; Sitohy, B. Exploiting the Biosynthetic Potency of Taxol from Fungal Endophytes of Conifers Plants; Genome Mining and Metabolic Manipulation. Molecules 2020, 25, 3000. [CrossRef]

6. El-Sayed, A.S.A.; Ali, D.M.I.; Yassin, M.A.; Zayed, R.A.; Ali, G.S. Sterol inhibitor "Fluconazole" enhance the Taxol yield and molecular expression of its encoding genes cluster from Aspergillus flavipes. Process Biochem. 2019, 76, 55-67. [CrossRef]

7. El-Sayed, A.S.A.; Fathalla, M.; Yassin, M.A.; Zein, N.; Morsy, S.; Sitohy, M.; Sitohy, B. Conjugation of Aspergillus flavipes taxol with porphyrin increases the anticancer activity of taxol and ameliorates its cytotoxic effects. Molecules 2020, 25, 263. [CrossRef] [PubMed]

8. El-Sayed, A.S.A.; Hassan, M.N.; Nada, H.M.S. Purification, immobilization, and biochemical characterization of 1-arginine deiminase from thermophilic Aspergillus fumigatus KJ434941: Anticancer activity in vitro. Biotechnol. Progress 2015, 31 , $396-405$. [CrossRef]

9. El-Sayed, A.S.A.; Mohamed, N.Z.; Safan, S.; Yassin, M.A.; Shaban, L.; Shindia, A.A.; Shad Ali, G.; Sitohy, M.Z. Restoring the Taxol biosynthetic machinery of Aspergillus terreus by Podocarpus gracilior Pilger microbiome, with retrieving the ribosome biogenesis proteins of WD40 superfamily. Sci. Rep. 2019, 9, 11534. [CrossRef] [PubMed] 
10. El-Sayed, A.S.A.; Abdel-Ghany, S.E.; Ali, G.S. Genome editing approaches: Manipulating of lovastatin and taxol synthesis of filamentous fungi by CRISPR/Cas9 system. Appl. Microbiol. Biotechnol. 2017, 101, 3953-3976. [CrossRef] [PubMed]

11. Kusari, S.; Singh, S.; Jayabaskaran, C. Rethinking production of Taxol®(paclitaxel) using endophyte biotechnology. Trends Biotechnol. 2014, 32, 304-311. [CrossRef] [PubMed]

12. Kusari, S.; Hertweck, C.; Spiteller, M. Chemical Ecology of Endophytic Fungi: Origins of Secondary Metabolites. Chem. Biol. 2012, 19, 792-798. [CrossRef] [PubMed]

13. Kusari, S.; Zühlke, S.; Spiteller, M. Effect of artificial reconstitution of the interaction between the plant camptotheca acuminata and the fungal endophyte fusarium solani on camptothecin biosynthesis. J. Nat. Prod. 2011, 74, 764-775. [CrossRef]

14. El-Sayed, A.S.A.; El Sayed, M.T.; Nada, H.S.; Hassan, A.E.; Yousef, E.K. Production and Characterization of Taxol as Anticancer Agent from Aspergillus terreus. J. Pure Appl. Microbiol. 2019, 13, 2055-2063. [CrossRef]

15. El enshasy, H.A.; El-Baz, A.F.; Ammar, E.M. Simultaneous production and decomposition of different rifamycins during Amycolatopsis mediterranei in shake flask and stirred tank bioreactor. Commun. Current Res. Educ. Topics Trends Appl. Microbiol. 2005, 315-321.

16. El-Sayed, A.S.; Shindia, A.A.; Zaher, Y. L-Amino acid oxidase from filamentous fungi: Screening and optimization. Annal. Microbiol. 2012, 62, 773-784. [CrossRef]

17. El-Sayed, A.S.A.; Safan, S.; Mohamed, N.Z.; Shaban, L.; Ali, G.S.; Sitohy, M.Z. Induction of Taxol biosynthesis by Aspergillus terreus, endophyte of Podocarpus gracilior Pilger, upon intimate interaction with the plant endogenous microbes. Process Biochem. 2018, 71, 31-40. [CrossRef]

18. El-Sayed, A.S.A.; Shindia, A.A.; Abouzeid, A.; Koura, A.; Hassanein, S.E.; Ahmed, R.M. Triggering the biosynthetic machinery of Taxol by Aspergillus flavipes via cocultivation with Bacillus subtilis: Proteomic analyses emphasize the chromatin remodeling upon fungal-bacterial interaction. Environ. Sci. Pollut. Res. 2021, 28, 39866-39881. [CrossRef] [PubMed]

19. Dickschat, J.S. Bacterial Diterpene Biosynthesis. Angew. Chem. Int. Ed. 2019, 58, 15964-15976. [CrossRef] [PubMed]

20. Wu, W.; Tran, W.; Taatjes, C.A.; Alonso-Gutierrez, J.; Lee, T.S.; Gladden, J.M. Rapid discovery and functional characterization of terpene synthases from four endophytic xylariaceae. PLoS ONE 2016, 11, e0146983. [CrossRef]

21. Prisic, S.; Xu, J.; Coates, R.M.; Peters, R.J. Probing the role of the DXDD motif in class II diterpene cyclases. ChemBioChem 2007, 8, 869-874. [CrossRef] [PubMed]

22. Christianson, D.W. Structural and Chemical Biology of Terpenoid Cyclases. Chem. Rev. 2017, 117, 11570-11648. [CrossRef]

23. Köksal, M.; Jin, Y.; Coates, R.M.; Croteau, R.; Christianson, D.W. Taxadiene synthase structure and evolution of modular architecture in terpene biosynthesis. Nature 2011, 469, 116-122. [CrossRef] [PubMed]

24. Huang, Q.; Roessner, C.A.; Croteau, R.; Scott, A.I. Engineering Escherichia coli for the synthesis of taxadiene, a key intermediate in the biosynthesis of taxol. Bioorg. Medic. Chem 2001, 9, 2237-2242. [CrossRef]

25. DeJong, J.H.M.; Liu, Y.; Bollon, A.P.; Long, R.M.; Jennewein, S.; Williams, D.; Croteau, R.B. Genetic engineering of taxol biosynthetic genes in Saccharomyces cerevisiae. Biotechnol. Bioengin 2006, 93, 212-224. [CrossRef] [PubMed]

26. Abdallah, I.I.; Pramastya, H.; Van Merkerk, R.; Sukrasno; Quax, W.J. Metabolic engineering of bacillus subtilis toward taxadiene biosynthesis as the first committed step for taxol production. Front. Microbiol. 2019, 10, 218. [CrossRef] [PubMed]

27. ElMekawy, A.; Hegab, H.M.; El-Baz, A.; Hudson, S.M. Kinetic properties and role of bacterial chitin deacetylase in the bioconversion of chitin to chitosan. Recent Pat. Biotechnol. 2013, 7, 234-241. [CrossRef]

28. El-Sayed, A.S.A.; Akbar, A.; Iqrar, I.; Ali, R.; Norman, D.; Brennan, M.; Ali, G.S. A glucanolytic Pseudomonas sp. associated with Smilax bona-nox L. displays strong activity against Phytophthora parasitica. Microbiol. Res. 2018, 207, 140-152. [CrossRef] [PubMed]

29. El-Baz, A.F.; Shetaia, M.Y.; Elkhouli, R.R. Xylitol production by candida tropicalis under different statistically optimized growth conditions. Afr. J. Biotechnol. 2011, 10, 15353-15363. [CrossRef]

30. Heinig, U.; Jennewein, S. Getting to the bottom of Taxol biosynthesis by fungi. Fungal Div. 2013, 60, 161-170. [CrossRef]

31. Artz, J.D.; Wernimont, A.K.; Dunford, J.E.; Schapira, M.; Dong, A.; Zhao, Y.; Lew, J.; Russell, R.G.G.; Ebetino, F.H.; Oppermann, U. Molecular characterization of a novel geranylgeranyl pyrophosphate synthase from Plasmodium Parasites. J. Biolog. Chem. 2011, 286, 3315-3322. [CrossRef]

32. El-Sayed, A.S.A.; Ali, G.S. Aspergillus flavipes is a novel efficient biocontrol agent of Phytophthora parasitica. Biol. Control 2020, 140, 104072. [CrossRef]

33. Hassan, A.; Sorour, N.M.; El-Baz, A.; Shetaia, Y. Simple synthesis of bacterial cellulose/magnetite nanoparticles composite for the removal of antimony from aqueous solution. Int. J. Env. Sci. Technol. 2019, 16, 1433-1448. [CrossRef]

34. El-Sayed, A.S.A.; Shindia, A.A.; Ali, G.S.; Yassin, M.A.; Hussein, H.; Awad, S.A.; Ammar, H.A. Production and bioprocess optimization of antitumor Epothilone B analogue from Aspergillus fumigatus, endophyte of Catharanthus roseus, with response surface methodology. Enzym. Microb. Technol. 2021, 143, 109718. [CrossRef]

35. El-Mekawy, A.; Hudson, S.; El-Baz, A.F.; Hamza, H.; El-Halafawy, K. Preparation of Chitosan Films Mixed with Super-absorbent Polymer and Evaluation of Its Haemostatic and Antibacterial Activities. J. Appl. Polymer Sci. 2010, 116, 3489-3496.

36. Edgar, R.C. MUSCLE: A multiple sequence alignment method with reduced time and space complexity. BMC Bioinform. 2004, 5, 113. [CrossRef] 
37. Tamura, K.; Peterson, D.; Peterson, N.; Stecher, G.; Nei, M.; Kumar, S. MEGA5: Molecular Evolutionary Genetics Analysis Using Maximum Likelihood, Evolutionary Distance, and Maximum Parsimony Methods. Molec. Biol. Evol. 2011, 28, $2731-2739$. [CrossRef]

38. Maamoun, H.S.; Rabie, G.H.; Shaker, I.; Alaidaroos, B.A.; El-Sayed, A.S.A. Biochemical and kinetic properties of tyrosinase from Aspergillus terreus and Penicillium copticola; Undecanoic acid is a potent enzyme inhibitor from Aspergillus flavus, endophyte of Moringa oleifera. Molecules 2021, 26, 1309. [CrossRef]

39. El-Sayed, A.S.A.; George, N.M.; Yassin, M.A.; Alaidaroos, B.A.; Bolbol, A.A.; Mohamed, M.S.; Rady, A.M.; Aziz, S.W.; Zayed, R.A.; Sitohy, M.Z. Purification and Characterization of Ornithine Decarboxylase from Aspergillus terreus; Kinetics of Inhibition by Various Inhibitors. Molecules 2019, 24, 2756. [CrossRef]

40. El-Sayed, A.S.A.; Shindia, A.A.; AbouZaid, A.A.; Yassin, A.M.; Ali, G.S.; Sitohy, M.Z. Biochemical characterization of peptidylarginine deiminase-like orthologs from thermotolerant Emericella dentata and Aspergillus nidulans. Enzym. Microb. Technol 2019, 124, 41-53. [CrossRef]

41. El-Sayed, A.S.A.; Shindia, A.A.; Zeid, A.A.A.; Yassin, A.M.; Sitohy, M.Z.; Sitohy, B. Aspergillus nidulans thermostable arginine deiminase-Dextran conjugates with enhanced molecular stability, proteolytic resistance, pharmacokinetic properties and anticancer activity. Enzym. Microb. Technol. 2019, 131, 109432. [CrossRef]

42. El-Sayed, A.S.A.; Abdel-Azeim, S.; Ibrahim, H.M.; Yassin, M.A.; Abdel-Ghany, S.E.; Esener, S.; Ali, G.S. Biochemical stability and molecular dynamic characterization of Aspergillus fumigatus cystathionine $\gamma$-lyase in response to various reaction effectors. Enzym. Microb. Technol. 2015, 81,31-46. [CrossRef] [PubMed]

43. Laemmli, U.K. Cleavage of structural proteins during the assembly of the head of bacteriophage T4. Nature 1970, 227, 680-685. [CrossRef] [PubMed]

44. El-Baz, A.F.; Shetaia, Y.M.; Elkhouli, R.R. Kinetic behavior of Candida tropicalis during xylitol production using semisynthetic and hydrolysate based media. Afr. J. Biotechnol. 2011, 10, 16617-16625. [CrossRef]

45. El-Baz, A.F.; Mohamed Sorour, N.; Shetaia, Y.M. Trichosporon jirovecii-mediated synthesis of cadmium sulfide nanoparticles. J. Basic Microbiol. 2016, 56, 520-530. [CrossRef]

46. El-Sayed, A.S.; Khalaf, S.A.; Aziz, H.A. Characterization of homocysteine $\gamma$-lyase from submerged and solid cultures of Aspergillus fumigatus ASH (JX006238). J. Microbiol. Biotechnol. 2013, 23, 499-510. [CrossRef]

47. El-Sayed, A.S.; Shindia, A.A. Characterization and immobilization of purified Aspergillus flavipes l-methioninase: Continuous production of methanethiol. J. Appl. Microbiol. 2011, 111, 54-69. [CrossRef]

48. El-Sayed, A.S.A.; Hassan, A.E.A.; Shindia, A.A.; Mohamed, S.G.; Sitohy, M.Z. Aspergillus flavipes methionine $\gamma$-lyase-dextran conjugates with enhanced structural, proteolytic stability and anticancer efficiency. J. Mol. Catal. B Enzym. 2016, 133, S15-S24. [CrossRef]

49. El-Sayed, A.S.A.; Ibrahim, H.; Sitohy, M.Z. Co-immobilization of PEGylated Aspergillus flavipes l-methioninase with glutamate dehydrogenase: A novel catalytically stable anticancer consortium. Enzym. Microb. Technol. 2014, 54, 59-69. [CrossRef] [PubMed]

50. El-Sayed, A.S.A.; Ruff, L.E.; Ghany, S.E.A.; Ali, G.S.; Esener, S. Molecular and Spectroscopic Characterization of Aspergillus flavipes and Pseudomonas putida L-Methionine $\gamma$-Lyase in Vitro. Appl. Biochem. Biotechnol. 2017, 181, 1513-1532. [CrossRef]

51. Kusari, S.; Lamshöft, M.; Spiteller, M. Aspergillus fumigatus Fresenius, an endophytic fungus from Juniperus communis L. Horstmann as a novel source of the anticancer pro-drug deoxypodophyllotoxin. J. Appl. Microbiol. 2009, 107, 1019-1030. [CrossRef] [PubMed]

52. Netzker, T.; Fischer, J.; Weber, J.; Mattern, D.J.; König, C.C.; Valiante, V.; Schroeckh, V.; Brakhage, A.A. Microbial communication leading to the activation of silent fungal secondary metabolite gene clusters. Front. Microbiol. 2015, 6, 299. [CrossRef] [PubMed]

53. Schroeckh, V.; Scherlach, K.; Nützmann, H.-W.; Shelest, E.; Schmidt-Heck, W.; Schuemann, J.; Martin, K.; Hertweck, C.; Brakhage, A.A. Intimate bacterial-fungal interaction triggers biosynthesis of archetypal polyketides in Aspergillus nidulans. Proc. Nat. Acad. Sci. USA 2009, 106, 14558-14563. [CrossRef]

54. Soliman, S.S.M.; Raizada, M.N. Interactions between Co-Habitating fungi Elicit Synthesis of Taxol from an Endophytic Fungus in Host Taxus Plants. Front. Microbiol. 2013, 4, 3. [CrossRef] [PubMed]

55. Soliman, S.; Tang, Y. Natural and engineered production of taxadiene with taxadiene synthase. Biotechnol. Bioeng. 2015, 112, 229-235. [CrossRef]

56. Pollak, F.C.; Berger, R.G. Geosmin and Related Volatiles in Bioreactor-Cultured Streptomyces citreus CBS 109.60. Appl. Environ. Microbiol. 1996, 62, 1295-1299. [CrossRef]

57. Izaguirre, G.; Hwang, C.J.; Krasner, S.W.; McGuire, M.J. Geosmin and 2-Methylisoborneol from Cyanobacteria in Three Water Supply Systems. Appl. Environ. Microbiol 1982, 43, 708-714. [CrossRef]

58. Dickschat, J.S.; Nawrath, T.; Thiel, V.; Kunze, B.; Müller, R.; Schulz, S. Biosynthesis of the off-flavor 2-methylisoborneol by the myxobacterium Nannocystis Exedens. Angew. Chem. 2007, 46, 8287-8290. [CrossRef] [PubMed]

59. Yamada, Y.; Kuzuyama, T.; Komatsu, M.; Shin-ya, K.; Omura, S.; Cane, D.E.; Ikeda, H. Terpene synthases are widely distributed in bacteria. Proc. Nat. Acad. Sci. USA 2015, 112, 857-862. [CrossRef] [PubMed]

60. Whittington, D.A.; Wise, M.L.; Urbansky, M.; Coates, R.M.; Croteau, R.B. Christianson, D.W. Bornyl diphosphate synthase: Structure and strategy for carbocation manipulation by a terpenoid cyclase. Proc. Nat. Acad. Sci. USA 2002, 99, 15375-15380. [CrossRef]

61. Zhang, P.; Zhou, P.-P.; Yu, L.-J. An endophytic taxol-producing fungus from Taxus $\mathrm{x}$ media, Aspergillus candidus MD3. FEMS Microbiol. Lett. 2009, 293, 155-159. [CrossRef] [PubMed] 
62. Zhang, X.; Wang, T.T.; Xu, Q.L.; Xiong, Y.; Zhang, L.; Han, H.; Xu, K.; Guo, W.J.; Xu, Q.; Tan, R.X. Genome Mining and Comparative Biosynthesis of Meroterpenoids from Two Phylogenetically Distinct Fungi. Angew. Chem Int. Ed. 2018, 57, 8184-8188. [CrossRef] [PubMed]

63. Zhang, P.; Zhou, P.-P.; Yu, L.-J. An Endophytic Taxol-Producing Fungus from Taxus media, Cladosporium cladosporioides MD2. Curr. Microbiol. 2016, 59, 227-232. [CrossRef]

64. Staniek, A.; Woerdenbag, H.; Kayser, O. Taxomyces andreanae: A Presumed Paclitaxel Producer Demystified? Planta Medica 2009, 75, 1561-1566. [CrossRef] [PubMed]

65. Williams, D.C.; Carroll, B.J.; Jin, Q.; Rithner, C.D.; Lenger, S.R.; Floss, H.G.; Coates, R.M.; Williams, R.M.; Croteau, R. Intramolecular proton transfer in the cyclization of geranylgeranyl diphosphate to the taxadiene precursor of taxol catalyzed by recombinant taxadiene synthase. Chem. Biol. 2000, 7, 969-977. [CrossRef]

66. Exposito, O.; Bonfill, M.; Moyano, E.; Onrubia, M.; Mirjalili, M.; Cusido, R.; Palazon, J. Biotechnological Production of Taxol and Related Taxoids: Current State and Prospects. Anti-Cancer Agents Med. Chem. 2009, 9, 109-121. [CrossRef] [PubMed]

67. Croteau, R.; Ketchum, R.E.B.; Long, R.M.; Kaspera, R.; Wildung, M.R. Taxol biosynthesis and molecular genetics. Phytochem. Rev. Proc. Phytochem. Soc. Eur. 2006, 5, 75-97. [CrossRef] [PubMed]

68. El-Sayed, A.S.; Shouman, S.A.; Nassrat, H.M. Pharmacokinetics, immunogenicity and anticancer efficiency of Aspergillus flavipes 1-methioninase. Enzym. Microb. Technol. 2012, 51, 200-210. [CrossRef]

69. El-Sayed, A.S.A.; Khalaf, S.A.; Azez, H.A.; Sitohy, B.; El-Baz, A.F. Production, bioprocess optimization and anticancer activity of Camptothecin from Aspergillus terreus and Aspergillus flavus, endophytes of Ficus elastica. Process Biochem. 2021, 107, 59-73. [CrossRef]

70. El-Sayed, A.S. Microbial l-methioninase: Production, molecular characterization, and therapeutic applications. Appl. Microbiol. Biotechnol. 2010, 86, 445-467. [CrossRef] [PubMed]

71. El-Sayed, A.S.A.; Yassin, M.A.; Ibrahim, H. Coimmobilization of 1 -methioninase and glutamate dehydrogenase: Novel approach for 1 -homoalanine synthesis. Biotechnol. Appl. Biochem. 2015, 62, 514-522. [CrossRef] [PubMed] 